
2 Research Square
Preprints are preliminary reports that have not undergone peer review.
They should not be considered conclusive, used to inform clinical practice, or referenced by the media as validated information.

\title{
Gridded distribution of total suspended particulate matter (TSP) and their chemical characterization over Delhi during winter
}

Ritu Jangirh

National Physical Laboratory CSIR

Sakshi Ahlawat

NPL: National Physical Laboratory

Rahul Arya

CSIR-NPL: National Physical Laboratory CSIR

Amab Mondal

CSIR-NPL: National Physical Laboratory CSIR

Lokesh Yadav

CSIR-NPL: National Physical Laboratory CSIR

Garima Kotnala

CSIR-NPL: National Physical Laboratory CSIR

Pooja Yadav

CSIR-NPL: National Physical Laboratory CSIR

Nikki Choudhary

CSIR-NPL: National Physical Laboratory CSIR

Martina Rani

CSIR-NPL: National Physical Laboratory CSIR

Rubiya Banoo

CSIR-NPL: National Physical Laboratory CSIR

Akanksha Rai

CSIR-NPL: National Physical Laboratory CSIR

Ummed Singh Saharan

CSIR-NPL: National Physical Laboratory CSIR

Neeraj Rastogi

Physical Research Laboratory

Anil Patel

Physical Research Laboratory

Shivani Shivani

IGDTUW: Indira Gandhi Delhi Technical University for Women

Ranu Gadi

IGDTUW: Indira Gandhi Delhi Technical University for Women

Priyanka Saxena

NEERI: National Environmental Engineering Research Institute CSIR

Narayanasamy Vijayan

CSIR-NPL: National Physical Laboratory CSIR

Chhemendra Sharma

CSIR-NPL: National Physical Laboratory CSIR

Sudhir Kumar Sharma

CSIR-NPL: National Physical Laboratory CSIR

Tuhin Kumar Mandal ( $\nabla$ tuhinkumarmandal@gmail.com )

National Physical Laboratory CSIR https://orcid.org/0000-0003-0142-1512

\section{Research Article}

Keywords: TSP, Organic carbon, Elemental carbon, WSIS, PAHs, PCA

Posted Date: May 27th, 2021

DOI: https://doi.org/10.21203/rs.3.rs-167612/v1

License: (c) (1) This work is licensed under a Creative Commons Attribution 4.0 International License. Read Full License 
Version of Record: A version of this preprint was published at Environmental Science and Pollution Research on October 22nd, 2021. See the published version at https://doi.org/10.1007/s11356-021-16572-w. 


\section{Abstract}

In the present study, total suspended particulate matter (TSP) samples were collected at 47 different sites ( 47 grids of $5 \times 5 \mathrm{~km}{ }^{2}$ area) of Delhi during winter (January-February 2019) in campaign mode. To understand the spatial variation of sources, TSP samples were analyzed for chemical compositions including carbonaceous species [organic carbon (OC), elemental carbon (EC) and water-soluble organic carbon (WSOC)], water-soluble total nitrogen (WSTN), watersoluble inorganic nitrogen (WSIN), polycyclic aromatic hydrocarbons (16 PAHs), water-soluble inorganic species $\left(\mathrm{WSIS}^{-}\left(\mathrm{F}^{-}, \mathrm{Cl}^{-}, \mathrm{SO}_{4}{ }^{2-}, \mathrm{NO}_{2}{ }^{-}, \mathrm{NO}_{3}{ }^{-}, \mathrm{PO}_{4}{ }^{3-}\right.\right.$, $\mathrm{NH}_{4}{ }^{+}, \mathrm{Ca}^{2+}, \mathrm{Mg}^{2+}, \mathrm{Na}^{+}$, and $\mathrm{K}^{+}$), and major \& minor trace elements (B, $\mathrm{Na}, \mathrm{Mg}, \mathrm{Al}, \mathrm{P}, \mathrm{S}, \mathrm{Cl}, \mathrm{K}, \mathrm{Ca}, \mathrm{Ti}, \mathrm{Fe}, \mathrm{Zn}, \mathrm{Cr}, \mathrm{Mn}, \mathrm{Cu}, \mathrm{As}, \mathrm{Pd}, \mathrm{F}$, and Ag). During the campaign, the maximum concentration of several components of TSP $\left(996 \mu \mathrm{g} / \mathrm{m}^{3}\right)$ was recorded at the Rana Pratap Bagh area representing a pollution hotspot of Delhi. The maximum concentrations of PAHs were recorded at Udhyog Nagar, a region close to heavily loaded diesel vehicles, small rubber factories, and waste burning areas. Higher content of $\mathrm{Cl}^{-}$and $\mathrm{Cl}^{-} / \mathrm{Na}^{+}$ratio (>1.7) suggests the presence of nonmarine anthropogenic sources of $\mathrm{Cl}^{-}$over Delhi. Minimum concentrations of OC, EC, WSOC, PAHs, and WSIS in TSP were observed at Kalkaji representing the least polluted area in Delhi. Enrichment factor $<5.0$ at several locations and a significant correlation of $\mathrm{Al}$ with $\mathrm{Mg}, \mathrm{Fe}, \mathrm{Ti}$, and $\mathrm{Ca}$ and $\mathrm{C} / \mathrm{N}$ ratio indicated the abundance of mineral/crustal dust in TSP over Delhi. Principal component analysis (PCA) was also performed for the source apportionment of TSP and extracted soil dust was found to be the major contributor to TSP followed by biomass burning, open waste burning, secondary aerosol, and vehicular emissions.

\section{Introduction}

Globally, air pollution has become a serious problem especially in metropolitan cities (Gurjar et al, 2004; Gerasopoulos et al. 2007; Balakrishnaiah et al. 2011; Bikkina et al. 2019). Total suspended particulate matter (TSP), the coarse mode pollutants, and their elemental compositions may cause serious effects on (soil, vegetation, and crop) and human health (Dockery et al. 1993; Ndiokwere et al. 1984; David et al. 2017). TSP is dominated by dust and other vegetation activities (Air Quality Monitoring Network, 2008), it includes airborne particles (solid and liquid) ranging from 0.005 to $100 \mu \mathrm{m}$ in diameter (Khillare et al. 2004). Several studies on TSP have been conducted in various parts of the world to examined their influence in atmospheric chemistry as well as ambient air quality (Chow et al. 2002; Christensen et al. 2004; Salma et al. 2005; Arditsoglou et al. 2005).

Developing countries like India experiences rapid growth in industrialization, urbanization, and human population which has increased the levels of pollutants in the atmosphere, declining its air quality and affecting human health and the environment (Goyal and Sidharta, 2003; Li et al. 2019; Bond et al, 2006, Izhar et al, 2016). In India alone, half a million people are affected and die due to poor air quality (Jerette et al. 2015). With more persistence of atmospheric particulates and their capability to react with each other, it has become more hazardous (Goyal and Sidharta, 2003). Delhi has experienced a growth in population at the rate of $3.3 \%$ and vehicles over 11 million in 2019 as per UN World Urbanization Prospects. Increasing urbanization over Delhi has made its people more vulnerable to aerosol air pollution. Delhi is now one of the most polluted cities in the world and the total respirable suspended particulate reported in Delhi is highest among the other cities of India (Hsu and Zomer, 2014). TSP concentration in Delhi has exceeded the Central pollution Control Board (CPCB), and World Health Organisation (WHO) prescribed limits (Guttikunda, and Gurjar, 2012).

TSP concentration varies according to the anthropogenic activities, natural sources, and meteorological conditions (relative humidity, solar radiation, wind speed etc.) in the area. The Influence of seasonal variations, mixing depth and physical properties of Delhi plays a key role in determining the pollution load (Holzworth, 1967, Dumka et al, 2016). The sources of the TSP decide the composition and its size distribution in the atmosphere (Contini et al. 2014). The suspended particulate has mineral dust, water-soluble organic, inorganic, and ionic species, heavy metals, organic and carbon, and sea-salts compounds as its major components (Ram and Sarin, 2012; Patel et al. 2020, Dumka et al., 2017). The identification of chemical constituents of TSP reflects the major sources and their associated processes affecting their physicochemical properties in the atmosphere (Perrino et al. 2009; Zhang et al. 2017). For source identification, the chemical characteristics of PM play an important role. Studies on potential sources of TSP in ambient air over Delhi were carried out by several researchers (Srivastava et al. 2007, 2008; Hazarika et al. 2015; Shandilya et al. 2006; Gupta et al. 2006), however, a comprehensive analysis of TSP is limited.

Air pollution complexity has increased in Delhi due to mixed sources such as vehicular emissions (emissions from gasoline and diesel vehicles), coal-based thermal power plants (Srivastava et al. 2007, 2008), small to medium scale industries (mainly electroplating, plastic, and metal alloy), road dust re-suspension (Pathak et al, 2013; Tandon et al. 2008; Sharma et al. 2015), construction activities, biomass (Monkkonen et al. 2004; Sharma et al. 2014), solid waste burning, domestic activities including cooking, and heating purposes (mainly include fuelwood, crop residue, and dung cake) (Mohan et al. 2011; Saud et al. 2012).

Delhi often faces uncontrolled pollution episodes during winter and therefore, the regulatory bodies have intended to measure the criteria pollutants primarily in the categories area (residential, industrial, and traffic junction). Apart from this, due to increased population and commercial activities, areas of different types of sources of pollutants have been increased over Delhi. Though the number of observational sites over Delhi has been increased by different regulatory bodies, gridded data of pollutants over Delhi is missing. The studies of chemical characteristics of PM over the Delhi region are mostly based on single or few locations. Gridded data of pollutants over Delhi, which is distributed over $1484 \mathrm{~km}^{2}$ is limited.

In this study, the spatial variation in concentration of TSP has been estimated at 47 locations of Delhi (47 grids of $5 \times 5 \mathrm{~km}^{2}$ ) during January - February 2019 . In addition, using the chemical components (OC, EC, WSOC, PAHs, WSIS, major and trace elements, etc.) of TSP an effort has been made to determine location-specific sources of TSP in Delhi (Stewart et al. 2020). In the present study, Principal component analysis (PCA) has been to investigate the potential source contributions to TSP in the ambient air of Delhi.

\section{Material And Methods}




\subsection{Study area}

Delhi is one of the major metropolitan cities of India located between the Himalayas and Aravali range and situated in North India $\left(28^{\circ} 12^{\prime}-28^{\circ} 63^{\prime} \mathrm{N}, 75^{\circ} 50^{\prime}-\right.$ $77^{\circ} 23^{\prime} \mathrm{E}$ ) at the sub-tropical belt and altitude ranges between $213-305 \mathrm{~m}$ above the sea level (asl). It is surrounded by Haryana on 3 sides and across the river Yamuna by Uttar Pradesh to the east and experiences a semi-arid climate. Delhi witnesses four distinct seasons (classified by Indian Meteorological Department, New Delhi): winter (January-February), summer or pre-monsoon (March-May), monsoon (June-September), and post-monsoon (OctoberDecember). The Winter season with minimum temperatures of about $4 \llbracket \mathrm{C}$ is moderately cold and short. The smog phenomena in Delhi during winter have increased so much that it can illustrate the emissions and impacts of pollution not only in Delhi but also in other regions of the country by activities such as crop residue burning and wood-burning (Singh et al. 2014; Kaskaoutis et al. 2014). During winter, particulate matter (PM) affects the health of about $30 \%$ of the total population of Delhi than any other pollutant causing serious respiratory and cardiovascular diseases (Gurjar et al. 2004). Emissions from different sources can be carcinogenic and hazardous for the atmosphere and human health. During the winter, atmospheric stability with conditions of low wind speed and temperature inversion lead to more atmospheric pollutants load in the lower layer of the atmosphere. Winter months are chilly (temperature: $\sim 2^{\circ} \mathrm{C}$ ) and observe intense fog and haze. Summers are generally very hot and dry (temperature: $47^{\circ} \mathrm{C}$ ) and observe frequent dust storms (soil and mineral dust). Due to low temperature, the high residence time of pollutant, low wind speed, precipitation, and low mixing height the pollutant concentration is high during winters (Karar et al. 2006, Dumka et al, 2016).

\subsection{Collection of samples}

TSP samples were collected using TSP samplers (high volume sampler) on Pall quartz fiber filters (diameter: $11.0 \mathrm{~cm}$ ) which were prebaked at $550^{\circ} \mathrm{C}$ for $6 \mathrm{~h}$. Filters were desiccated for $24 \mathrm{~h}$ before and after the sampling for its conditioning. Quartz filters were pre-weighed using a microbalance (resolution: $\pm 10 \mu \mathrm{g}$ ). Ambient air sampling was carried out at $1.5 \mathrm{~m}$ height above the ground level using a portable TSP Sampler with a flow rate of $0.459 \mathrm{lpm}$ for $4 \mathrm{~h}$ (daytime: 10:00-14:00 h) at 47 sites in Delhi during January-February, 2019 (winter) in a campaign mode. After sampling, the filters were put in desiccators for $24 \mathrm{~h}$ and then weighed, and TSP concentration (in $\mu \mathrm{g} / \mathrm{m}^{3}$ ) was calculated. Quartz filters have been widely used to collect particulate matter for subsequent determination of carbon content by thermal-optical analysis (Zhu et al., 2010; 2012; 2014; Chen et al., 2010). However, the absorption of gaseous organics could occur during sampling because the quartz filters have a large surface area, which could lead to overestimation of particulate organic carbon. On the other hand, the volatilization of particulate organic carbon from the filter would result in the underestimation of the particulate organic carbon. Nitrate can also give negative interference due to the dissociation of volatile ammonium nitrate. Semi-volatile organic compounds may also cause sample weight loss. To eliminate these uncertainties in OC/EC measurement and other chemical analysis quartz back quartz (QBQ) filters were used during sampling apart from the field blank filters (Sharma et al., 2014).

\subsection{Chemical Analysis}

\section{Organic carbon (OC) and Elemental Carbon (EC)}

A small punch of $0.536 \mathrm{~cm}^{2}$ of each filter was cut and analyzed for OC and EC concentrations by using OC/EC carbon analyzer (Model: DRI 2001A, Make: Atmoslytic Inc., Calabasas, CA) using IMPROVE-A protocol (Chow et al. 2002). OC/EC analyzer run on a principle of preferential oxidation of OC and EC on which sample is heated to different temperature plateaus $\left(140^{\circ} \mathrm{C}, 280^{\circ} \mathrm{C}, 480^{\circ} \mathrm{C}, 580^{\circ} \mathrm{C}, 740^{\circ} \mathrm{C}\right.$, and $\left.840^{\circ} \mathrm{C}\right)$. OC is oxidized from the sample deposited on the filter in pure helium atmosphere at $140^{\circ} \mathrm{C}, 280^{\circ} \mathrm{C}, 480^{\circ} \mathrm{C}$, and $580^{\circ} \mathrm{C}$ to estimate the $\mathrm{OC}$ components $(\mathrm{OC} 1, \mathrm{OC} 2, \mathrm{OC} 3$, and $\mathrm{OC} 4)$, its function shows that organic carbon can be volatilized in a non-oxidizing helium atmosphere whereas $\mathrm{EC}$ undergoes oxidation in a $98 \%$ helium and $2 \%$ oxygen at $580^{\circ} \mathrm{C}, 740^{\circ} \mathrm{C}, 840^{\circ} \mathrm{C}$ to estimate the EC components (EC1, EC2, and EC3) relies on the fact that elemental carbon must be combusted by an oxidizer. The main function of the optical component of the analyzer is for the correction of pyrolysis and carbonizes OC compounds into EC. Calibration of the OC/EC analyzer was performed by $4.8 \%$ of $\mathrm{CO}_{2}+$ balance $\mathrm{He}$ gas along with known amounts of KHP (potassium hydrogen phthalate) and sucrose solution (Sharma et al. 2015). Each sample was analyzed in triplicate to estimate the repeatability error (estimated as $4-7 \%$ ).

\section{Water-Soluble Inorganic Species (WSIS)}

The sample filters were $\left(2 \times 2 \mathrm{~cm}^{2}\right)$ cut into smaller pieces and then extracted in de-ionized water (resistivity: $18.2 \mathrm{M} \Omega$-cm) for 45 minutes, three times $\left(45^{\star} 3=\right.$ $135 \mathrm{~min}$ ) in ultra-sonicator. The extract was filtered using nylon membrane filters (size: $0.22 \mu \mathrm{m}$ ) and then stored the extracted sample in polypropylene sample bottles. Concentration of inorganic anions $\left(\mathrm{F}^{-}, \mathrm{Cl}^{-}, \mathrm{NO}_{2}{ }^{-}, \mathrm{SO}_{4}{ }^{2-}, \mathrm{NO}_{3}{ }^{-}\right.$and $\left.\mathrm{PO}_{4}{ }^{2-}\right)$ and cations $\left(\mathrm{Na}^{+}, \mathrm{NH}_{4}{ }^{+}, \mathrm{K}^{+}, \mathrm{Mg}^{2+}\right.$, and Ca$\left.{ }^{2+}\right)$ were determined by using Ion Chromatograph (Dionex-ICS-3000, USA) under suppressed conductivity. Solution for mobile phase used for anions $20 \mathrm{mM} \mathrm{NaOH}$ as an eluent and cations were analyzed by $5 \mathrm{mM}$ MSA (methane sulphonic acid) as eluent was prepared for the analysis. Anions were determined by using an lonPac-AS11-HC analytical column $(4 \times 250 \mathrm{~mm}$, Dionex, USA) with a guard column (IonPac-AS11-HC, 4×50mm, Dionex, USA), ASRS-300, 4mm anion micro-membrane suppressor. Cations were determined by using a separation column of lonPac CS-17-HC ( $4 \times 250 \mathrm{~mm}$, Dionex, USA) with a guard column lonPac CS-17-HC $(4 \times 50 \mathrm{~mm}$, Dionex, USA) with a suppressor CSRS-300 (4mm, Dionex, USA). The calibration curve was displayed on the screen for each analytical run and chromatogram was processed by Chromeleon software. QA/QC of WSIS analysis of TSP samples has been assured by calibrating each ionic species with a known standard value (standard line). The calibration standards have been prepared by the National Institute of Standards and Technology (NIST, USA) traceable certified standard solution for calibration of IC [the IC was standardized using NIST-USA traceable Standard Reference Material, SRM 3184 (Bromide), 3182 (Chloride), 3183 (Fluoride), 3185 (Nitrate), 3186 (Phosphate), 3181 (Sulphate), SRM 3129 (Lithium), 3152 (sodium), 3141 (Potassium), 3131 (Magnesium), 3109 (Calcium)]. The analytical errors were estimated to be $3-7 \%$ based on triplicate $(n=3)$ analysis. Blank filters (cations: $\mathrm{Li}^{+}, \mathrm{Na}^{+}, \mathrm{NH}_{4}{ }^{+}, \mathrm{K}^{+}$, $\mathrm{Ca}^{2+}$ and $\mathrm{Mg}^{2+}$ and anions: $\mathrm{F}^{-}, \mathrm{Cl}^{-}, \mathrm{NO}_{3}{ }^{-}$and $\mathrm{SO}_{4}{ }^{2-}$ ) were also analyzed and concentration in each sample was corrected for their respective average blank concentrations (Sharma et al. 2014). 
For WSOC, a circular punch of $7.065 \mathrm{~cm}^{2}$ area from each sample was extracted in $20 \mathrm{ml}$ of deionized water (specific resistance: $18.2 \mathrm{M} \Omega$-cm) using an ultrasonicator for 30 minutes $(10 \times 3=30 \mathrm{~min})$. The concentrations of water-soluble organic carbon (WSOC) and water-soluble total nitrogen (WSTN) were measured using a total organic carbon analyzer (TOC, Shimadzu, model TOC-L CPH) and total nitrogen monitor (Shimadzu, model TNM-L ROHS, assembled with TOC-L), respectively. The WSOC was measured as non-purgeable organic carbon (NPOC), where the samples were acidified by $5 \% \mathrm{HCl}$ and spurge for 1.0 minute) (zero air as sparging gas, flow: $80 \mathrm{ml} / \mathrm{min}$ ) to remove the inorganic carbon (IC) fraction from the solution in the TOC analyzer (Rastogi et al. 2015). The IC-free solution was then transferred to the combustion column (heated at $680^{\circ} \mathrm{C}$ ), where it was oxidized to form $\mathrm{CO}_{2}$ via oxidation by Pt-Al $\mathrm{O}_{3}$ catalyst. This $\mathrm{CO}_{2}$ was then detected by a non-dispersive infrared (NDIR) detector. The calibration curve was prepared using laboratory-made multiple standards from $1000 \mathrm{mg} / \mathrm{L}$ stock solution of potassium hydrogen phthalate (KHP). Patel et al (2020) have described in detail the estimation of WSOC and WSON in particulates samples.

The nitrogenous compounds were decomposed and oxidized to nitrogen monoxide NO in the combustion tube $\left(680^{\circ} \mathrm{C}\right)$ filled with Pt-Al $\mathrm{O}_{3}$ catalyst. The carrier gas carries NO to the TNM-L system where it is measured for WSTN in the chemiluminescence detector. Further, the $1000 \mathrm{mg} / \mathrm{L}$ stock solution of $\mathrm{KNO}_{3}$ was diluted and run in the same way as the sample to obtain the calibration curve. Multiple blank filter punches were also analyzed for WSOC and WSTN concentration, and their respective concentration was subtracted from each sample. Further, the concentration of WSON was estimated by taking the difference between WSTN and water-soluble inorganic nitrogen (WSIN). The N mass fraction from $\mathrm{NH}_{4}{ }^{+}, \mathrm{NO}_{2}{ }^{-}$and $\mathrm{NO}_{3}{ }^{-}$was considered as WSIN (i.e., a sum of $\mathrm{NH}_{4}{ }^{+}-\mathrm{N}_{1} \mathrm{NO}_{2}{ }^{-} \mathrm{N}$, and $\mathrm{NO}_{3}{ }^{-}-\mathrm{N}$ ). There is no analytical method to measure directly the concentration of WSON. WSON is comparatively a small fraction of water-soluble total nitrogen (WSTN) (Rastogi et al., 2011).

\section{Polar Organic Compounds}

The sample filters were extracted twice with $15 \mathrm{ml}$ dichloromethane (DCM) by using an ultra-sonicator for 15 min. The extracted sample was then transferred to a rotatory flask to reduce the sample to $1 \mathrm{ml}$ using a rotary evaporator at $30^{\circ} \otimes 40^{\circ} \mathrm{C}$. The extracted samples were then filtered by a membrane filter (PVDF; size: $0.5 \mu \mathrm{m}$ micro-syringe) and transferred into the vials. The sample was stored in a deep-freezer at $-20^{\circ} \mathrm{C}$ for further analysis. Extracted sample was then analyzed for organic compounds by using a gas chromatograph (GC) (Shimadzu, GC-2010 Plus) system which is equipped with an Rtx-5 molecular sieve column $\left(0.25 \mu \mathrm{m}\right.$ thickness). The system maintained at $50^{\circ} \mathrm{C}$ for $5 \mathrm{~min}$ initially, then increased at the rate of $5^{\circ} \mathrm{C} / \mathrm{min}-150^{\circ} \mathrm{C}$ held for $5 \mathrm{~min}$, then $8^{\circ} \mathrm{C} / \mathrm{min}-250^{\circ} \mathrm{C}$ held for $10 \mathrm{~min}$ and then $10^{\circ} \mathrm{C} / \mathrm{min}-300^{\circ} \mathrm{C}$ for $5 \mathrm{~min}$. The organic compounds were identified based on their retention time with standards. Three different classes of organic compounds were identified by following standards- for n-alkanes [40147 U C8-C40 alkanes, calibration standard (Sigma-Aldrich)], for PAHs [polycyclic aromatic hydrocarbons 16 solutions (36979) (Sigma-Aldrich)] and phthalates [4S8231-SS EPA phthalate ester mix (Sigma-Aldrich)]. Calibration curves were obtained for different standards for the quantification of organic compounds. 16 PAHs are Naphthalene (Nap), Acenephthene (Ac), Acenaphthylene (Acy), Anthracene (Anth), Phenanthrene (Ph), Fluorene (FI), Fluoranthene (Flth), Pyrene (Py), Benzo(a)anthracene (BaA), Chrysene (Chy), Benzo(a)Pyrene (BaP), Benzo(b)Fluoranthene (BbF), Benzo(k)Flurorathene (BkF), Benzo(ghi)Perylene (BghiP), Dibenzo(a,h)Anthracene (DahA) and Indeno (1,2,3-cd) Pyrene (IP).

\section{Trace Elements}

The quantitative analysis of elements ( $\mathrm{Na}, \mathrm{Mg}, \mathrm{Al}, \mathrm{Fe}, \mathrm{P}, \mathrm{S}, \mathrm{Cl}, \mathrm{K}, \mathrm{Ti}, \mathrm{Ca}, \mathrm{As}, \mathrm{Pd}$, F, and Ag) in TSP samples was performed by using Wavelength Dispersive X-ray Fluorescence Spectrometer (WD - XRF). $2.0 \mathrm{~cm}$ diameter size of quartz filter (area: $3.14 \mathrm{~cm}^{2}$ ) was used for the analysis of major and trace elements in TSP by WD-XRF (Rigaku ZSX Primus). The XRF spectrometer has components such as a sealed X-Ray tube for excitation, scintillation counter (heavy element detector), flow proportional counter (light element detector), end window, and Rh target. The analysis was carried out at $36^{\circ} \mathrm{C}$ temperature with a $2.4 \mathrm{~kW}$ tube rating under vacuum conditions. ZSX software (Rigaku Corporation, Japan) was used for quantitative analysis and data procurement by parameter method. The instrument WD-XRF was calibrated periodically using micro-matter thin-film standards (Watson et al., 1999).

After the elemental analysis using X-ray Fluorescence, the same filters were re-analyzed by inductively coupled plasma-optical emission spectrometry (ICPOES) for verification of concentrations of elements ( $\mathrm{B}, \mathrm{Zn}, \mathrm{Cr}, \mathrm{Mn}, \mathrm{Cu}, \mathrm{Cd}, \mathrm{Pb}, \mathrm{Co}, \mathrm{Ni}, \mathrm{Bi}, \mathrm{Li}, \mathrm{Sr}$, and $\mathrm{Ga}$ ) in TSP. Filters were extracted and transferred to PTFE vessel filled with $5 \mathrm{ml}$ concentration of $\mathrm{HNO}_{3}, 10 \mathrm{ml}$ concentration of $5 \%$ of $\mathrm{HNO}_{3}$, and $2 \mathrm{ml}$ concentration of $\mathrm{H}_{2} \mathrm{O}_{2}$ in digestion tube for 50 min. After that, it was allowed to cool properly and $10 \mathrm{ml}$ of $5 \%$ of $\mathrm{HNO}_{3}$ was added, then it was allowed to stand for about 30 min. The solution was filtered by Whatman filter and syringe filter $(0.42 \mu \mathrm{m})$ and makeup to a volume of $25 \mathrm{ml}$ and analyzed using ICP-OES.

\section{Principle Component Analysis (PCA)}

PCA a multivariate statistical tool, can identify patterns in data and disclose the information about differences and similarities. In PCA, assuming a linear relationship between the total mass concentration and the contributions of each species, PCA factorized the data in numerous steps (Song et al. 2006). PCA was performed for TSP data over Delhi to identify possible sources. Principle components to be retained were decided by examining the screed plot and \% of the variance. The eigenvalue for extracted factor was taken more than 1. First, dimensionless standardized form has been transformed from chemical composition data.

$$
Z_{i j}=\frac{\mathrm{C}_{i j}-\overline{\mathrm{C}} j}{\sigma j}
$$


Where $i=1, \ldots . . \mathrm{n}$ samples; $j=1 \ldots$. elements, $\mathrm{C}_{i j}$ is the concentration of elements $j$ in sample $i$; and $\mathrm{C} j$ and $\sigma_{j}$ are the arithmetic mean concentration and the standard deviation for element $j$, respectively. The PCA model is expressed as

$$
Z_{i j}=\sum_{k=1}^{p} \mathrm{~g}_{\mathrm{ik}} \mathrm{h}_{\mathrm{kj}}
$$

Where $k=1, \ldots \ldots . . p$ sources; $g_{i k}$ and $h_{k j}$ are the factor loading and the factor score, respectively. The equation helped in solving the eigenvector decomposition (Song et al. 2006)

APCS method is used later based on factor loading scores of PCA, which estimates source contribution and source profile quantitatively (Thurson and Spengler, 1985; Henry and Hidy, 1979). Since PCA results are normalized for the data, thus the factor for true zero is derived as

$$
(Z o) j=\frac{0-\bar{c}_{j}}{\sigma_{j}}=-\frac{\overline{\mathrm{c}}_{j}}{\sigma_{j}}
$$

APCS is also known as rescaled scores and further linear regression can be derived from the following equation,

$$
\mathrm{M} i=\zeta 0+\sum_{k=1}^{p} \zeta \mathrm{APCS} k i
$$

where $\mathrm{M} i$ is the measured mass concentration in sample $i$ and $\zeta_{0}$ denote the mass contribution in the PCA made by the sources uncounted. APCS $k i$ is the rotated absolute component score for source $k$ in sample $i$, and $\zeta k A P C S_{k i}$ is the mass contribution in the sample $i$ made by source $k$. This follows the regression for the sample concentrations on the APCS which gets each identified source's estimated mass contribution. (Song et al. 2006).

\section{Results And Discussion}

The concentrations of TSP were estimated at the 47 sites of Delhi during January-February 2019 and their chemical components were also analyzed to assess the ambient air quality of Delhi as well as possible sources of TSP over the region. The results of these analyses are discussed in subsequent subsection.

\subsection{Mass concentration}

Figure-1(a-b) shows the spatial map of sampling sites and TSP concentration over Delhi. Details of sampling sites are summarized in Supplementary Table S1. TSP concentration at all the 47 sites exceeded the 24 -hourly ambient air quality standard levels of SPM (CPCB, 2009) with the highest concentration at Rana Pratap Bagh $\left(996 \mathrm{\mu} \mathrm{m}^{-3}\right)$, which is situated in the northwest district of Delhi. Large spatial variation was observed in the concentration of TSP. If the whole data set are divided into 5 bins ranges then those ranges are $246-396 \mu \mathrm{g} \mathrm{m}^{-3}$ with 2 sites, $396-546 \mu \mathrm{g} \mathrm{m}^{-3}$ with 6 sites, $546-696 \mu \mathrm{g} \mathrm{m}^{-3}$ with 11 sites, $696-846 \mu \mathrm{g} \mathrm{m}^{-3}$ with 15 sites, $846-996 \mu \mathrm{g} \mathrm{m}^{-3}$ with 13 sites (see Supplementary Figure S1). Such a large variation is noticed at a large number of sites with higher mass concentration only and it suggests the heterogeneity in local sources and its strength for TSP concentration. Previous studies (Pandey et al. 2002; Sridhar et al. 2010; Nagpure et al. 2013; Li et al. 2014; Kumar et al. 2015, Kumar et al. 2016, Kumar et al. 2018) have also reported high values of TSP ranged from 198-690 $\mathrm{gg} \mathrm{m}^{-3}$ over Delhi. Hazarika et al. (2015) have presented size segregated particulate matter for fine TSP (size ranges < 1 and 1-2.5 $\mu \mathrm{m}$ ) from 303.6 to $416.2 \mu \mathrm{g} \mathrm{m}^{-3}$ and coarse TSP (> $10 \mu \mathrm{m}$ ) from 162.9 to $262.8 \mu \mathrm{g} \mathrm{m}^{-3}$ over Delhi. Goswami and Baruha (2008) have simulated daily variation of TSP over Delhi and compared it with CPCB data for the period of 2000-2005. Monthly variation of TSP data show wintertime maxima (600 $\mu \mathrm{g}$ $\mathrm{m}^{-3}$ ) and identified the relative roles of vehicular emission, dust, and domestic appliances. Mohan et al. (2011) have estimated the spatial distribution of TSP using AERMOD, ADMS, and ADMS-Urban models and compared with eight stations CPCB data for the year 2000 and 2004. Srivastava et al. (2009) have shown ITO, traffic junction as the most polluted site $\left(>550 \mu \mathrm{g} \mathrm{m}^{-3}\right)$ among six sites $\left(250-575 \mu \mathrm{g} \mathrm{m}^{-3}\right)$ of Delhi. Shandilya et al. (2007) have shown the variation of TSP concentration from 553.4 to $827.6 \mathrm{\mu g} \mathrm{m}^{-3}$ at the rural and urban industrial sites of Delhi. Ram and Sarin (2010) have reported lower concentration of TSP at three urban sites of northern India (Allahabad: $300 \pm 90 \mu \mathrm{g} \mathrm{m}^{-3}$; Kanpur: $141 \pm 73 \mu \mathrm{g} \mathrm{m}^{-3}$; Hisar: $177 \pm 64 \mu \mathrm{g} \mathrm{m}^{-3}$ ) as compared to the present study. The spatial distribution of TSP concentration may be unable to define possible sources, so further chemical analysis has been performed. The mean concentration of TSP and its chemical compositions are summarized in Supplementary Table S2.

3.2 Carbonaceous components in TSP (OC, EC, WSOC, OC/EC, WSOC/OC)

Figure 2 (a-d) represents the spatial map of OC, EC, TCAs, and WSOC over Delhi. Large variation (8-fold) in OC concentration from $17.0 \mu \mathrm{g} \mathrm{m}^{-3}$ to $^{147.9} \mu \mathrm{g} \mathrm{m}^{-}$ ${ }^{3}$ (average $60.4 \pm 30.4 \mathrm{\mu g} \mathrm{m}^{-3}$ ) suggests the geospatial variation of OC over Delhi (Figure-2a) due to the variation in sources types and strength. The maximum concentration of OC was found at Rana Pratap Bagh $\left(148 \mu \mathrm{g} \mathrm{m}^{-3}\right)$ followed by Karala village $\left(135 \mu \mathrm{g} \mathrm{m}^{-3}\right)$. RP Bagh, a residential and nearby slum area with very high vehicular activities and a huge jagari industries (a product of sugarcane) may be a potential source of $\mathrm{OC}$, whereas, Karala village in the region of many food processing industries, different agriculture practices followed by open biomass burning, vehicular emissions, and dust re-suspension. Mean OC mass has contributed approximately $9 \%$ to TSP with large variability (12-33\%) over Delhi (see supplementary Figure S3a). EC concentration over Delhi has varied from 5.8-47.1 $\mu^{g^{-3}}$ (average; $15.8 \pm 8.3 \mu \mathrm{g} \mathrm{m}^{-3}$ ) (Figure-2b). The EC mass also showed a large spatial variation (2-8\%) with a mean contribution of $5 \%$ to TSP. Ram and Sarin (2010) have reported higher EC concentration in the rural area (Jaduguda: $11.6 \pm 2.0 \mu \mathrm{g} \mathrm{m}{ }^{-3}$ ) than urban sites (Allahabad: $8.1 \pm 1.7 \mu \mathrm{g} \mathrm{m}^{-3}$; Kanpur $6.2 \pm 3.7 \mu \mathrm{g} \mathrm{m}^{-3}$ and Hisar: $8.5 \pm 2.2 \mu \mathrm{g} \mathrm{m}^{-3}$ ) in TSP. Similar to OC, the highest concentration of EC was also found at Rana Pratap Bagh $\left(47 \mathrm{\mu g} \mathrm{m}^{-3}\right)$. A most interesting point is the disappearance of the high value of EC at Karala village. A high value of OC and EC at Rana 
Pratap Bagh indicates the OC and EC would be from the same type of sources such as combustion of biomass fuel and fossil fuels, whereas, high OC and low EC peak at Karala village suggest the biomass burning as one of the responsible source (Mondal et al, 2021 and Grided distribution of emission estimates of carbonaceous aerosols from biomass burning over NCT- Delhi, in preparation). In addition to these two sites, some of the sites showed high variability particularly in the north and east Delhi (E8 and F10 in supplementary Table-S1). Very low concentration of EC was found at few locations of southwest districts (grid F5, F6, and G5 in supplementary Table-S1) and southeast districts (F3, G5, G3 in supplementary Table-S1) where OC concentration was also low. Using TSP collected from September 2006 to April 2007, Miyazaki et al. (2009) have estimated the mean OC concentration of the order of $68.4 \pm 37.9 \mu \mathrm{g} \mathrm{m}^{-3}$ over Delhi. Figure-2c represents the spatial map of total carbonaceous aerosol (TCAs $=1.6 * \mathrm{OC}+\mathrm{EC}$ ) over Delhi. TCAs has varied from $32.9 \mu \mathrm{g} \mathrm{m}^{-3}$ to $283.7 \mu \mathrm{g}$ $\mathrm{m}^{-3}$ (average $\left.=112.5 \pm 56.0 \mu \mathrm{g} \mathrm{m}^{-3}\right)$. Two potential hotspots are noticed at Rana Pratap Bagh $\left(283.7 \mu \mathrm{g} \mathrm{m}^{-3}\right)$ and Karala village $\left(252.2 \mu \mathrm{g} \mathrm{m}{ }^{-3}\right)$, respectively. Ram and Sarin (2010) have shown that carbonaceous aerosol accounts for 30-35\% of TSP at urban and rural sites of northern India, whereas, in the present study mean contribution of total carbonaceous aerosol was $23-26 \%$ of TSP (see supplementary Figure S3a). Sharma et al. (2018a, b) have shown a lower contribution of total carbonaceous aerosol to $\mathrm{PM}_{2.5}(29 \%)$ and $\mathrm{PM}_{10}(24 \%)$ except winter when the contribution was $29 \%$. Similar studies (Mandal et al. 2014; Sharma et al. 2014; Bisht et al. 2015; Gupta et al. 2018; Sharma et al. 2018a, b; Gadi et al. 2019, Dumka et al, 2017) have reported a higher contribution of carbonaceous aerosol to PM. Spatial variation in carbonaceous aerosol over Delhi may be due to the variation of emission from the vehicle and local industries, biomass burning apart from common factors like lower boundary layer, advection of pollutants from Punjab and Haryana from agricultural residue burning site to the observed sites. The mass closer for organic matter (OM) alone accounts for approximately $18 \%$ which is higher than OC ( $9 \%$ ) (see supplementary Figure S4). Some of the OM comes from domestic heating and cooking purpose (Perrino et al. 2011) and fuel-burning (Chan et al. 1997). There can be a significant amount of primary biogenic particles in TSP e.g., pollen, plant debris, fungi, etc. EC mainly comes from combustion sources including exhaust of vehicle-driven sources which contributed $2 \%$ of the total TSP concentration.

Figure-2d represents the spatial map of WSOC over Delhi. Like OC and EC, WSOC also showed large variation (10-fold) with the lowest concentration at Aram Bagh $\left(4.5 \mu \mathrm{g} \mathrm{m}^{-3}\right)$ and the highest at Rana Pratap Bagh $\left(43.8 \mu \mathrm{g} \mathrm{m}^{-3}\right)$. The mean concentration of WSOC over Delhi was $17.6 \pm 8.1 \mu \mathrm{g} \mathrm{m}{ }^{-3}$. WSOC contributes $29 \%$ of OC over Delhi (see supplementary Figure S5). When WSOC is less than $50 \%$ of the total OC, it means more insoluble carbon is dominant at all the locations of Delhi. More than $51 \%$ WSOC of OC concentration was only observed at Majnu Ka Tila, a tourist bus stand along the NH-1. WSOC shows reasonable dependence on OC $\left(R^{2}=0.56\right)$ with a slope of 0.21 (see Supplementary Figure S6). Ram and Sarin (2010) have shown the contribution of WSOC concentration to OC was more at a rural site (45\%) than urban sites (35\%) and stronger dependence of WSOC on OC $\left(R^{2}=0.86\right)$ at urban sites. Miyazaki et al. (2009) reported a similar range of WSOC $\left(8-55 \mu \mathrm{g} \mathrm{m}^{-3}\right)$ in TSP samples over Delhi during winter contributing $31 \pm 11 \%$ of OC during the study period. Waterinsoluble inorganic carbon (WSIC) (OC-WSOC) ranges from $12.5 \mu \mathrm{g} \mathrm{m}^{-3}$ to $104.1 \mu \mathrm{g} \mathrm{m}^{-3}$ with an average value of $42.8 \pm 22.3 \mu \mathrm{g} \mathrm{m}{ }^{-3}$. WSIC normally comes from fossil fuel combustion, whereas, the variability in the WSOC concentration at various points might be due to a combination of various factors like varying emission sources, sources strength, SOA formations, and meteorological conditions. WSOC may be used as a measure of SOA. Biomass burning also contributes to primary WSOC and secondary WSOC (by emitting VOCs forming SOA, Rastogi et al. 2015).

In the present study, OC/EC ratio has varied from 2.1 to 5.9 (average $3.9 \pm 1.0$ ) (in supplementary Table S3). Spatial variation of OC/EC ratio has been given in supplementary Figure S7(a). Ram and Sarin (2010) have reported higher variability in OC/EC ratio (2.4-14.5) in TSP at urban sites of northern India indicating dominant contribution from biomass burning sources (wood-fuel and agriculture waste). Sharma et al. (2014) have reported OC/EC ratio in the range of 3.85.8 (average $4.38 \pm 2.36$ ) in $\mathrm{PM}_{10}$ over Delhi. Lower OC/EC ratio indicates either the absence of secondary organic aerosol (SOA) over Delhi or the dominance of fossil fuel combustion sources Concentration of OC and EC are the culmination of combustion of fossil fuel and biomass fuel, OC/EC ratio may indicate their competitive contributions. The highest OC/EC ratio at Karala village indicates the possibility of enhanced biomass burning as well as SOA formation. Bhowmik et al. (2020) have reported OC/EC ratio for the two in Delhi sites $(5.9 \pm 3.4,5.9 \pm 4.8)$ in $\mathrm{PM}_{2.5}$ during winter 2018. An average OC/EC ratio of 6.6 was reported for biomass combustion by Saarikoski et al. (2008) and 7.3 for wood-burning emissions in particular (Sandradewi et al. 2008), whereas a low OC/EC ratio of 1.1 was found for traffic emissions (Sandradewi et al. 2008). Schauer et al. (2002) have also reported OC/EC values of 1.0-4.2 and 16.8-40.0 for diesel/gasoline-powered vehicular exhausts and wood combustion. In a new inventory for on-road vehicular emission, Jaiprakash et al. (2018) have also proposed OC/EC ratio (0.45-30) for different types of fuels (Diesel, Gasoline, CNG) used in vehicles of India. Venkatraman et al. (2005) have reported OC/BC ratio in the range $0.28-9.09$ for few biofuels widely used in India. Saud et al. (2012) have reported OC/EC ratio in the range of 2.3-5.68 for different types of residential fuels (fuelwood: 2.3, crop residue: 3.68, and dung cake: 5.01 ) used over Delhi. The scatter plot between OC and EC concentrations over Delhi shows a significant correlation $\left(R^{2}=0.74, \mathrm{p}<0.05\right)$, indicating their origin from common sources (see Supplementary Figure S6). Spatial variability of OC/EC ratio over Delhi indicates heterogeneity in the contribution of emission of biomass fuels and fossil fuels, biogenic emission, and/or secondary aerosol formation.

WSOC/OC ratio indicates the photochemical activity and/or aging of the aerosols during the transport (Pio et al. 2007). WSOC is either produced by a gasphase reaction from volatile organic carbon (Miyazaki et al. 2007; Pio et al. 2007; Weber et al. 2007) and biomass burning and/or vehicular emissions (Saarikoski et al. 2008). In the present study, WSOC/OC ratio has varied from 0.10 to 0.51 at the sites of Delhi (see in supplementary Table S3 and Supplementary Figure S7b). The mean WSOC/OC ratio is $0.30 \pm 0.10$ and comparable to that reported by Miyazaki et al. (2009) over Delhi. They reported day $(0.37 \pm 0.09)$ and night $(0.25 \pm 0.09)$ variation of WSOC/OC ratios in TSP and found photochemical production SOA over Delhi. In the present study, frequency distribution of WSOC/OC ratio shows Gaussian spread i.e., 0.10-0.20 (6 sites), 0.20-0.29 (14 sites), $0.29-0.39$ (14 sites), $0.39-0.48$ (11 sites), $0.48-0.51$ (2 sites) (see supplementary Figure S8). Such a pattern suggests the variability in emission sources, their strength, and contribution from SOA at sites of Delhi. Lower WSOC/OC ratios could be due to the poor solubility of organic constituents from the combustion of liquid fuels (diesel, gasoline, etc.) in water. Ram and Sarin (2010) reported the variation of average WSOC/OC ratio in TSP from 0.32 to 0.79 for the sampling sites in the IGP. The higher contribution of WSOC to OC can be explained by enhanced photochemical production of polar compounds. Higher OC concentration and lower WSOC/OC ratio at Rana Pratap Bagh indicate the presence of more advected aged aerosols in addition to local sources. In contrast, enhanced photochemical production of polar compounds in the vehicular emission at Majnu Ka Tila, a tourist bus stand along the $\mathrm{NH}-1$, making the highest WSOC/OC ratio (0.51) and the possible formation of SOA (see supplementary Figure S7b). Similar to the present study, (Kondo et al. (2007) have also reported that $35 \%$ of OC was water-soluble at an urban location in 
Tokyo, Japan. Higher WSOC/OC ratio (see supplementary Figure S7b) at Karala village supports the SOA formation as observed expected by higher OC/EC ratio. Jian et al. (2005) had reported that average WSOC/OC ratios were 0.30 at an urban location (Nanjing). Ram et al. (2010, 2012) have reported a large seasonal variation of WSOC/OC ratio of (0.21-0.70) at Kanpur. Saarikoski et al. (2008) have reported a value of 0.27 for vehicular emissions over an urban environment in Helsinki (northern Europe). An earlier study by Cheung et al. (2009) had reported the variation of WSOC/OC ratios from 0.06 to 0.19 in the diesel particles emitted from light-duty vehicles. Wu et al. (2019) have reported a higher WSOC/OC ratio $(0.68 \pm 0.40)$ at a Himalayan site of Nepal indicating a higher water-soluble component of organic aerosol to OC and the possible formation of SOA in winter. From the above discussion, it has been found that fossil fuel burning and biomass fuels burning leading SOA have contributed to carbon-containing aerosols over Delhi.

\subsection{Water Soluble lonic Species (WSIS) in TSP}

Water-soluble ionic species (WSIS) has contributed 19\% of TSP (see supplementary Figure S3). Most abundant water-soluble species are Ca ${ }^{2+}(33 \%, 47.0 \mu \mathrm{g}$ $\left.\mathrm{m}^{-3}\right), \mathrm{SO}_{4}{ }^{2-}\left(19 \%, 27.2 \mu \mathrm{g} \mathrm{m}^{-3}\right), \mathrm{Cl}^{-}\left(19 \%, 25.8 \mu \mathrm{g} \mathrm{m}^{-3}\right), \mathrm{Na}^{+}\left(9 \%, 12.2 \mu \mathrm{g} \mathrm{m}^{-3}\right), \mathrm{NO}_{3}{ }^{-}\left(5 \%, 9.3 \mu \mathrm{g} \mathrm{m}^{-3}\right)$ and $\mathrm{NH}_{4}{ }^{+}(5 \%)$ in WSIS over Delhi (see supplementary Figure S9a). Most of the water-soluble species showed maxima at Rana Pratap Bagh, the site of highest TSP. The trend for the mean concentration of WSIS in Delhi was as: $\mathrm{Ca}^{2+}>\mathrm{SO}_{4}{ }^{2-}>\mathrm{Cl}^{-}>\mathrm{Na}^{2+-}>\mathrm{NO}_{3}{ }^{-} \geq \mathrm{NH}_{4}{ }^{2+}>\mathrm{NO}_{2}{ }^{-} \geq \mathrm{K}^{+}>\mathrm{Mg}^{2+}>\mathrm{PO}_{4}{ }^{2-}>\mathrm{F}^{-}$. The concentration for cation species ranges from $33.1 \mu \mathrm{mg} \mathrm{m}^{-3}$ at $\mathrm{Vasant}$ Kunj to $236.2 \mu \mathrm{g} \mathrm{m}^{-3}$ at Majnu a Tila. In an earlier section, it has been observed that a higher WSOC/OC (0.51) ratio at Majnu Ki Tila indicated the photochemical activity leading to the formation of SOA, in contrast, a lower WSOC/OC ratio at Rana Pratap Bagh supported advection of aged aerosol. A higher concentration of WSIS at Majnu Ki Tila supports the formation of SOA aerosol as compared to Rana Pratap Bagh. The lowest concentration of WSIS was found at several locations of Delhi (Surakhpur, Baprola, Kalkaji, Aram Bagh, and Bakhtawarpur). The ratios of the sum of equivalent concentrations of anions to cations (A/C) were used as an indicator to analyze the acidity of the different environments (Shen et al, 2009). During the study period, the A/C ratio varied between 0.28 and 0.78 with an average of 0.47 at our site indicating an alkaline environment (see supplementary Fig. $9 \mathrm{~b}$ ).

\subsubsection{Primary WSIS $\left(\mathrm{Na}^{+}, \mathrm{K}^{+}, \mathrm{Ca}^{+2}, \mathrm{Mg}^{+2}\right.$, and $\left.\mathrm{Cl}^{-}\right)$}

Figure 3 (a-e) shows the spatial map of primary water-soluble ionic species over Delhi. Primary WSIS constitutes $67 \%$ of total water-soluble ionic species (see

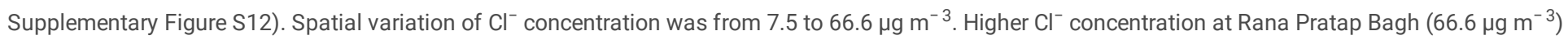
is followed by Manglapuri $\left(49.3 \mathrm{\mu g} \mathrm{m}^{-3}\right)$, Zafrabad metro $\left(22.2 \mu \mathrm{g} \mathrm{m}^{-3}\right)$, and Govindpuri $\left(15.9 \mu \mathrm{g} \mathrm{m}^{-3}\right)$ (Fig. 3a). These sites are characterized by highly anthropogenic activities (see supplementary Table S3). $\mathrm{Cl}^{-}$is found in normally coarser particles and its formation might be from the mechanisms i.e., sea salt transformation and photochemical reaction (Chattopadhayay, 2012), biomass burning (Saud et al. 2013), and use of fertilizers (Bakeer et al. 2016). In addition to open waste burning waste to energy (WTE) plants installed at Sukhdev Vihar-Okhla, Ghazipur, and Bawana plastic uses municipal solid waste (MSW) as input. The polyvinyl chloride (PVC) plastics content of MSW is a significant contributor to emissions of chlorinated dibenzo-p-dioxins (dioxins) that are associated with MSW combustion (Shepherd, 1993). Gunthe et al (2021) have argued that the high local concentration of gas-phase hydrochloric acid, possibly emitted from plastic-contained waste burning and industry has contributed to enhanced Cl-concentration over Delhi. Since sites are far from the sea, photochemical reaction, open waste burning could be the major sources along with the coal combustion in nearby slums area. Saxena et al. (2017) found $20.1 \mu \mathrm{g} \mathrm{m}^{-3}$ of $\mathrm{Cl}^{-}$in $\mathrm{PM}_{10}$, in the present study, the mean concentration of $\mathrm{Cl}^{-}$in TSP was $27.2 \mu \mathrm{g} \mathrm{m}^{-3}$.

Like $\mathrm{Cl}^{-}$spatial variation of $\mathrm{Na}^{+}$is from 1.0 to $56.4 \mu \mathrm{g} \mathrm{m}^{-3}$. The highest concentration of $\mathrm{Na}^{+}$was observed at Rana Pratap Bagh (56.4 $\mu \mathrm{g} \mathrm{m}{ }^{-3}$ ) (Fig. $3 \mathrm{~b}$ ). Heavy traffic load and open burning near the location (Bi et al. 2011), resuspension of soil dust derived from roadside (Parrington et al. 1983; Tandon et al. 2008; Chattopadhyay, 2012) could be the possible source of $\mathrm{Na}^{+}$in the ambient air. A strong correlation $\left(\mathrm{R}^{2}\right.$ : 0.84$)$ between $\mathrm{Na}^{+}$and $\mathrm{Cl}^{-}$suggests the common source (see supplementary Figure S10). $\mathrm{Cl}^{-} / \mathrm{Na}^{+}$ratio in the marine aerosol is 1.7 (Cauer, 1951; Chesselet et al. 1972). In the present study, $\mathrm{Cl}^{-} / \mathrm{Na}^{+}$ratio varies from 1.1 to 12.9 (3.3 \pm 2.5 ) over Delhi (see supplementary Table S4). $\mathrm{Cl}^{-} / \mathrm{Na}^{+}$at some sites (Surakhpur village, Mahavir Enclave, VIPS Pitampura, Kalkaji, Dakshinpuri, Jaunapur, Rana Pratap Bagh, Wazirbad and R.K. Puram, Sec-4) is lower than marine aerosol, whereas, other sites (Govindpuri, Andrews Ganj, Bhogal, Neelwal village, Pooth Khurd) reported very higher $\mathrm{Cl}^{-} / \mathrm{Na}^{+}$which indicates the several anthropogenic secondary sources of $\mathrm{Cl}^{-}$other than marine (sea salt). Low-level flow (northeast) during winter rules out the possibility of marine sources.

Normally the main source of $\mathrm{K}^{+}$is considered as soil but fine particles of $\mathrm{K}^{+}$may be released into the atmosphere through the burning of plant materials (leaves, vegetable straw) (Cooper, 1980, Saud et al. 2013; Sharma et al. 2016). $\mathrm{K}^{+}$showed high concentration at Nizampur village (11.7 $\mu \mathrm{g} \mathrm{m}^{-3}$ ), Rana Pratap Bagh $\left(9.7 \mu \mathrm{g} \mathrm{m}^{-3}\right)$, Trilokpuri $\left(8.3 \mu \mathrm{g} \mathrm{m}^{-3}\right)$, and Karala village $\left(7.5 \mu \mathrm{g} \mathrm{m}^{-3}\right)$ and the major sources might be responsible for biomass burning emissions and road dust (Fig. 3c). A high concentration of $\mathrm{K}^{+}$was found near the industrial region since Nizampur village is situated near Bahadurgarh which is an industrial region. The concentration for anion throughout Delhi ranges from $31.6 \mu \mathrm{g} \mathrm{m}^{-3}$ at Mahavir enclave to $217.3 \mu \mathrm{g} \mathrm{m}^{-3}$ at Majnu ka Tila. Higher $\mathrm{K}^{+} / \mathrm{Na}^{+}(0.12-$ $3.03)$ in the present study than seawater $\mathrm{K}^{+} / \mathrm{Na}^{+}$ratio (0.036) rules out the sea salt as a source over Delhi (see supplementary Table S4). Correlation between $\mathrm{K}^{+}$and EC ( $\left.\mathrm{R}^{2}: 0.27\right), \mathrm{K}^{+}$and OC ( $\left.\mathrm{R}^{2}: 0.4\right)$ confirms the role of biomass burning and fossil fuel burning over the study area (see Supplementary Figure S10). Moreover, a morphological study by Goel et al (2020) has given the possibility of $\mathrm{NaCl}$ and $\mathrm{KCl}$ as predominant compounds i.e., crustal sources in the ambient air of Delhi (see supplementary Figure S10). nss- $\mathrm{K}^{+} / \mathrm{EC}$ ratio is indicative of fossil fuel burning, whereas, $\mathrm{K}^{+} / \mathrm{Cl}^{-}$ratio and $\mathrm{Cl}^{-} / \mathrm{Na}^{+}$ratio provides the information of closure to the location of sources of $\mathrm{Cl}^{-}$. Spatial variation of nss- $\mathrm{K}^{+} / \mathrm{EC}$ ratio, $\mathrm{K}^{+} / \mathrm{Cl}^{-}$ratio, and $\mathrm{Cl}^{-} / \mathrm{Na}^{+}$ratio suggests the role of various location-specific sources of fossil fuel and primary sources respectively (see supplementary Figure S11).

$\mathrm{Mg}^{2+}$ showed high spatial variability $\left(0.96-13.44 \mu \mathrm{g} \mathrm{m}^{-3}\right)$ over Delhi. The highest concentration of $\mathrm{Mg}+$ has observed at Rana Pratap Bagh followed by Dakshinpuri $\left(11.1 \mathrm{\mu g} \mathrm{m}^{-3}\right)$ and Raghubir Nagar $\left(10.1 \mathrm{gg} \mathrm{m}^{-3}\right)$ (Fig. 3d). Construction dust is the major source of $\mathrm{Mg}^{+}$. $\mathrm{Mg}^{+} / \mathrm{Na}^{+}$ratio $(0.22-1.54)$ higher than seawater $\mathrm{Mg}^{+} / \mathrm{Na}^{+}$ratio (0.12) rules out the role of sea salt in ambient air of Delhi (see supplementary Table S4). Correlation between Mg ${ }^{+}$with OC ( $\mathrm{R}^{2}$ : 0.5 ) suggests soil dust as a source (see supplementary Figure S12). The high concentration for $\mathrm{Ca}^{2+}$ commonly showed at Rana Pratap Bagh (153.9 $\mu \mathrm{g} \mathrm{m}^{-3}$ ) (Fig. 3e) as we already know it exposed to high traffic congestion, dust, and municipality waste burning near the location. Correlation between Ca ${ }^{+}$and $0 \mathrm{C}\left(\mathrm{R}^{2}\right.$ : 
0.3) suggests soil dust as a source. A strong correlation between $\mathrm{Ca}^{+}$and $\mathrm{Mg}^{+}\left(\mathrm{R}^{2}: 0.61\right)$ suggests crustal as a common source. Heavy vehicular load, burning of coal nearby slum area, boilers in the small factories and local biomass combustion might have contributed to $\mathrm{F}^{-}$concentration at Rana Pratap Bagh (1.1 $\mu \mathrm{g}$ $\left.\mathrm{m}^{-3}\right)$ followed by Shastri Bazaar $\left(1.0 \mu \mathrm{g} \mathrm{m}^{-3}\right)$ and Raghubir Nagar $\left(0.7 \mu \mathrm{g} \mathrm{m}^{-3}\right)$ (Fig. 3f).

\subsubsection{Secondary WSIS $\left(\mathrm{SO}_{4}{ }^{2-}+\mathrm{NO}_{3}{ }^{-}+\mathrm{NO}_{2}{ }^{-}+\mathrm{NH}_{4}{ }^{+}+\mathrm{PO}_{4}{ }^{3-}\right)$}

Secondary water-soluble ions $\left(\mathrm{SO}_{4}{ }^{2-}+\mathrm{NO}_{3}{ }^{-}+\mathrm{NO}_{2}{ }^{-}+\mathrm{NH}_{4}{ }^{+}+\mathrm{PO}_{4}{ }^{3-}\right.$ ) constitutes $33 \%$ of total water-soluble ions (see supplementary Figure S9). Figure 4 (a-e) shows the spatial map of secondary water-soluble inorganic ions over Delhi. $\mathrm{SO}_{2}, \mathrm{NO}_{x}, \mathrm{NH}_{3}$ and $\mathrm{PO}_{4}{ }^{3-}$ are $\mathrm{precursors}^{-} \mathrm{SO}_{4}{ }^{2-},\left(\mathrm{NO}_{3}{ }^{-}+\mathrm{NO}_{2}{ }^{-}\right), \mathrm{NH}_{4}{ }^{+}$and $\mathrm{PO}_{4}{ }^{3-}$, respectively under suitable conditions.

In a megacity like Delhi, the possibility of diesel driven automobile, fossil fuel emissions, small and medium industries, and thermal power plants in and around Delhi-NCR (Suneja et al. 2020) might be responsible for the emission of $\mathrm{SO}_{2}$ which might have been converted to $\mathrm{SO}_{4}{ }^{2-}$ depending upon their prevailing meteorological conditions. $\mathrm{SO}_{2}$ also release from conventional fuels like coal and furnace oils (Chattopadhayay, 2012). Suneja et al. (2020) have reported the long-term trend of $\mathrm{SO}_{2}$ in ambient air over Delhi showing winter maxima and also concluded that the thermal power plants were one of the major local sources of $\mathrm{SO}_{2}$ over the Delhi region. Under the colder atmospheric condition, other processes such as metal-catalyzed oxidation of $\mathrm{SO}_{2}$, the aqueous phase of $\mathrm{H}_{2} \mathrm{O}_{2} / \mathrm{O}_{3}$ oxidation of $\mathrm{SO}_{2}$ could be major pathways of $\mathrm{SO}_{4}{ }^{2-}$ formation (Seinfeld and Pandis, 2006, Jai Prakash et al.2016; Collett et al. 1990). The combination of all the sources leads to the highest concentration of $\mathrm{SO}_{4}{ }^{2-}$ (Fig. 4a) at Rana Pratap Bagh $\left(53.9 \mu \mathrm{g} \mathrm{m}^{-3}\right)$.

Heavy vehicular load and open burning near railway crossing have led to high $\mathrm{NO}_{2}{ }^{-}$concentration (15.8 $\left.\mu \mathrm{g} \mathrm{m}^{-3}\right)$ at Rana Pratap Bagh (Fig. $\left.4 \mathrm{~b}\right)$. Lower concentration of $\mathrm{NO}_{2}{ }^{-}$at Vasant Kunj sec-C $\left(0.9 \mu \mathrm{g} \mathrm{m}^{-3}\right)$ followed by Pandwala Khurd village $\left(1.1 \mathrm{\mu g} \mathrm{m}^{-3}\right)$ and Andrews $\mathrm{Ganj}\left(1.5 \mu \mathrm{g} \mathrm{m}{ }^{-3}\right)$ might be connected to lower traffic emission. Jahangirpuri $\left(20.3 \mathrm{\mu g} \mathrm{m}^{-3}\right)$ with heavy traffic congestion and biomass burning reported the highest concentration of $\mathrm{NO}_{3}{ }^{-}$ (Fig. 4c). The mass ratios of $\mathrm{NO}_{3}{ }^{-} / \mathrm{nss}_{-} \mathrm{SO}_{4}{ }^{2-}$ higher than unity indicated that the sources of particles were mainly from mobile sources. Conversely, the mass ratios of $\mathrm{NO}_{3}{ }^{-} / \mathrm{nss}^{-\mathrm{SO}_{4}}{ }^{2-}$ lower than unity suggested that the sources of particles mainly came from stationary sources (Li et al, 2016). In the present study, $\mathrm{NO}_{3}{ }^{-} / \mathrm{nss}-\mathrm{SO}_{4}{ }^{2-}$ ratio is less than unity suggests the role of stationary sources. High spatial variation of $\mathrm{NO}_{3}{ }^{-} / \mathrm{nss}^{-} \mathrm{SO}_{4}{ }^{2-}$ ratio more than unity in several locations of Delhi indicates the vehicular emission as one of the source TSP (see supplementary Figure S13).

The highest concentration of $\mathrm{NH}_{4}{ }^{+}$was reported at Rana Pratap Bagh $\left(12.6 \mu \mathrm{g} \mathrm{m}^{-3}\right)$ followed by Trilokpuri $\left(12.5 \mu \mathrm{g} \mathrm{m}{ }^{-3}\right.$ Poothkhurd $\left(12.4 \mu \mathrm{g} \mathrm{m}{ }^{-3}\right)$ and Aram Bagh $\left(10.1 \mathrm{~g} \mathrm{~m}^{-3}\right.$ ) (Fig. 4d). Biomass burning, traffic congestion, and industrial emissions at all these three sites could be sources of $\mathrm{NH}_{4}{ }^{+}$. During winter months secondary organic aerosol formed from acidic gases mostly emitted from fossil fuel and biomass fuel combustion sources could be possible sources (Saxena et.al, 2017). The minimum concentration is found over South-East Delhi. Soil dust, secondary inorganic formation, biomass burning, fossil fuels burning could be possible sources of WSIS in TSP. spatial distribution of $\mathrm{PO}_{4}{ }^{3-}$ (Fig. 4e) shows the highest concentration at Mandawali (5.1 $\mu$ g $\mathrm{m}^{-3}$ ).

Correlations between $\mathrm{NH}_{4}{ }^{+}$vs $\mathrm{Cl}^{-}\left(R^{2}: 0.56\right), \mathrm{NH}_{4}{ }^{+} \mathrm{vs} \mathrm{NO}_{3}{ }^{-}\left(R^{2}: 0.54\right)$ and $\mathrm{NH}_{4}{ }^{+} \mathrm{vs} \mathrm{SO}_{4}{ }^{2-}\left(R^{2}: 0.42\right)$ suggest the possibility of secondary inorganic formation over Delhi (see supplementary Figure S14). Mass closer for inorganic ions (sulphate, chloride, nitrate, ammonium) by adding all the elements together accounted for approx. $25 \%$ of TSP, which is higher than a chemical determination of total ions. (see supplementary Figure S4).

\subsection{Nitrogen-containing components in TSP (WSTN, WSIN, WSON)}

Figure 5 (a-c) represents the spatial map of water-soluble total nitrogen (WSTN), water-soluble inorganic nitrogen (WSIN), and water-soluble organic nitrogen (WSON) over Delhi. Spatial variation of WSIN/TSP mass ratio, WSON/WSTN mass ratio, and WSIN/WSTN is given Supplementary Figure S15.

WSTN concentration $\left(15.9 \pm 9.2 \mathrm{~N} \mathrm{\mu g} \mathrm{m}^{-3}\right.$ ) constitutes $2.3 \%$ of TSP (see supplementary Figure S3) and higher than the reported value (3.51-4.87 $\mathrm{N}^{\mathrm{Ngm}}{ }^{-3}$ )

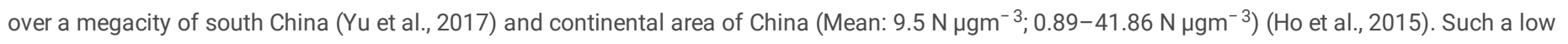
percentage in TSP ascribed to the fine mode existence of particulate nitrogenous compounds (Spokes et al. 2000; Cornell et al. 2001). Zhang et al. (2002) have shown $31 \%$ organic nitrogen in $\mathrm{PM}_{2.5}$ in North Carolina in winter. The higher value of WSTN could be due to the presence of biomass burning and vehicular emissions. Large usages of nitrogenous fertilizers $\left(\mathrm{NH}_{3}\right)$ over IGP and large vehicular emission $\left(\mathrm{NO}_{2}\right.$, $\left.\mathrm{NH}_{3}\right)$ over Delhi might have contributed to an inorganic component, whereas, local biomass burning, municipality waste burning, space heating enhanced the organic component.

Mean water-soluble inorganic nitrogen (WSIN) calculated from the nitrogen component of $\mathrm{NH}_{4}{ }^{+}, \mathrm{NO}_{3}{ }^{-}, \mathrm{NO}_{2}{ }^{-}$was $8.5 \pm 4.9 \mu \mathrm{g} \mathrm{m}{ }^{-3}\left(1.7-21.7 \mathrm{~N} \mu \mathrm{gm}{ }^{-3}\right.$ ) accounting for $52 \%$ of WSTN (see supplementary Figure S16 (a-b)). The location of the highest concentration of WSTN (Pooth Khurd: $39.4 \mathrm{~N}_{\mu} \mathrm{Km}^{-3}$ ) does not

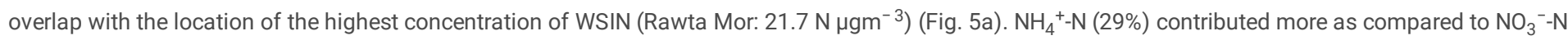
$(14 \%)$ and $\mathrm{NO}_{2}{ }^{-}-\mathrm{N}(9 \%)$ to WSTN concentration (Fig. 5c). The highest concentration of $\mathrm{NH}_{4}{ }^{+}$at Rawta mor indicate possible conversion of $\mathrm{NH}_{3}$. $\mathrm{Mainly}^{-}$ was associated with coarse particles due to gaseous nitric acid (Münevver and Mustafa, 2018). Surakhpur reported the lowest concentration of WSTN (1.9 $\mu \mathrm{g}$ $\left.\mathrm{m}^{-3}\right)$ and WSIN $\left(1.7 \mu \mathrm{g} \mathrm{m}^{-3}\right)$ in Delhi.

WSON varied from 1.7 to $21.7 \mu \mathrm{g} \mathrm{m}^{-3}$ and contributing only $1.2 \%$ of TSP. The mean concentration of WSON was $7.4 \pm 6.1 \mu \mathrm{g} \mathrm{Nm}{ }^{-3}$, calculated subtracting WSIN from WSTN, and its accounts for $48 \%$ of WSTN (see supplementary Figure S16). It resembles the mean concentrations of WSON (4.2 N $\mu g m^{-3}$; $0.41-$ $17.5 \mathrm{~N} \mathrm{\mu gm}^{-3}$ ) in a continental area of China (Ho et al., 2015) and WSON concentration of $3.56 \mathrm{~N} \mathrm{\mu gm}^{-3}$ in TSP in Beijing (Duan et al., 2009). WSON concentration over Delhi is almost 10 times higher than normal and polluted conditions in the Coastal Area of Seto Inland Sea (0.24 and $0.31 \mathrm{~N}_{\mu} \mathrm{gm} \mathrm{m}^{-3}$ ) (Nakamura et al., 2020). Zhang et al. (2002) have reported concentrations of water-soluble organic nitrogen (WSON) ranged from $0.04-0.81 \mathrm{~N}_{\mu \mathrm{gm}}{ }^{-3}$ 
representing $20 \%$ of the WSTN and $~ 18 \%$ of $\mathrm{PM}_{2.5}$ from northern California. Mace et al. (2003) have reported organic $\mathrm{N} 45 \%$ (mean concentration $0.05 \mathrm{~N}$ $\mu \mathrm{gm}^{-3}$ ) and $43 \%$ (mean concentration $0.85 \mathrm{~N} \mathrm{\mu gm}^{-3}$ ) of the total $\mathrm{N}$ in wet and dry season aerosol samples respectively over the Amazon basin. Yu et al. (2017) have reported WSON and WSON/WSTN ratio $0.47-0.73$ and $12-34 \%$ respectively. Hegde and Kawamura (2017) have reported a comparatively low value of WSON (0.2-1.0 $\mu \mathrm{g} \mathrm{m}^{-3}$; average $\left.0.42 \pm 0.31 \mu \mathrm{g} \mathrm{m}^{-3}\right)$ over marine site Thumba. The maximum concentration of WSON was observed at Majnu Ka Tila $\left(21.6 \mathrm{\mu g} \mathrm{m}^{-3}\right)$ where the highest concentration of WSOC is also observed. Anthropogenic sources (Biomass burning, vehicular emission) might have contributed to WSON at Majnu Ka Tila. Minimum concentration of WSON was observed at Surakhpur village $\left(0.2 \mu \mathrm{g} \mathrm{m} \mathrm{m}^{-3}\right)\left(\mathrm{Fig}^{\mathrm{S}} 5 \mathrm{~b}\right)$.

A good correlation between WSIN and WSTN $\left(\mathrm{R}^{2}=0.64\right)$ suggests that in the significant number of samples, WSTN is evenly contributed by the sum of $\mathrm{NO}_{3}{ }^{-}$, $\mathrm{NO}_{2}{ }^{-}$and $\mathrm{NH}_{4}{ }^{+}$(see supplementary Figure S17). Asian soils contain $40 \%$ of nitrogen which might turn into water-soluble nitrate as suggested by Kawmura et al. (2004). Therefore, the soil could be one of the major sources of water-soluble nitrate. In addition, sources of inorganic ionic species are mostly from gas precursors of the atmosphere (Seinfeld and Pandis, 1998). Being a food basket of India, IGP uses a lot of nitrogenous fertilizers which are converted to $\mathrm{NH}_{4}{ }^{+}$. Vehicular emission contains a large amount of $\mathrm{NH}_{3}$ which eventually converted to $\mathrm{NH}_{4}{ }^{+}$and contributes $\mathrm{NH}_{4}{ }^{+}-\mathrm{N}$ (Sharma et al., 2016). A very poor correlation between TC and TN $\left(R^{2}<0.09\right)$ resembles the observation of Hegde and Kawamura (2017) over the Thumba region of Trivandrum. Agnihotri et al. (2011) have argued that the mean TC/TN ratio over Delhi $(16.9 \pm 4.2)$ might indicate crop reside and fuelwood burning in the open fields as sources of TN.

Sources of WSON can be deduced by comparing other diagnostics parameters of particulate matter such $\mathrm{OC}, \mathrm{EC}, \mathrm{K}^{+}, \mathrm{SO}_{4}{ }^{2-}, \mathrm{NO}_{3}{ }^{-}, \mathrm{Ca}^{+}$, etc $(\mathrm{Duan}$ et al. 2009$)$. WSON is originated from a variety of sources including both natural and anthropogenic. Anthropogenic may include agricultural activities, fuel combustion, biomass burning, industrial activity, etc and natural sources are mineral dust, algal blooms, natural biomass burning (Mace et al. 2003; Münevver and Mustafa, 2018). Laskin et al. (2009) have suggested slow smoldering burning that leads to incomplete combustion of pyrolysis products as responsible for the presence of a large number of nitrogen-containing organic carbon species in the biomass burning aerosol samples.

WSON shows no correlation with OC when data of the 47 sites are considered (see supplementary Figure S18). This could indicate that sources of WSON and OC are not common except few. To identify which site represents a better correlation between WSON and OC, WSON/OC ratio has been calculated and it shows a large variation from 0.01 to 0.40 . WSON/OC ratio has been divided into three ranges, i.e., $0.01-0.10,0.10-0.20$, and $>0.20$. Yu et al. (2017) have reported WSON/OC ratio between $0.30-0.51$ over a megacity of south China. A stronger significant correlation ( 0.65$)$ is observed between WSON and OC at 13 sites of Delhi (see supplementary Table-S5) when WSON/OC is within the range of $0.10-0.20$ and as compared to the other two ranges $0.01-0.10\left(R^{2}=0.40\right.$ ) and $>0.20\left(R^{2}=0.32\right)$. OC is mainly originated from the incomplete combustion of fuels (biomass, bio-fuel, municipality waste, etc.) and fossil fuels (coal, charcoal, etc). Sites with a WSON/OC ratio of $0.10-0.20$ have common sources which might be biomass burning and fossil fuel combustion. At other sites, sources of OC do not match with that of WSON.

Data of EC and WSON over 47 locations results in no good correlation between EC and WSON. EC and WSON at all the stations may not have common sources over Delhi except a few. WSON/EC ratio varied from 0.02-1.75 (see Supplementary Table S6). To identify which site represents a better correlation between WSON and EC, WSON/EC ratio has been considered and divided into three ranges i.e., 0.02-0.29; 0.30-1.0, and above 1.0. Correlation ( $\left.R^{2}\right)$ between WSON and EC, for WSON/EC ratios in the ranges of 0.30 to 1.0 and above 1.0 is 0.67 and 0.63 respectively (see supplementary Figure S19). Only at those sites having a higher WSON/EC ratio (0.30 -1.0 and above) have common sources of WSON and EC.

$\mathrm{K}^{+}$is an important tracer of biomass burning as OC. WSON does not show any good correlation with $\mathrm{K}+$ when the whole data set of 47 sites are considered. To identify which site represents a better correlation between WSON and OC, Accordingly, data of K + has been divided into three sets based on WSON/OC ratio. When $0.10<$ WSON/OC $>0.20$, correlation $\left(R^{2}=0.22\right)$ between WSON and $\mathrm{K}^{+}$(see supplementary Figure S20a) indicate likely biomass burning possible source at those 11 sites where WSON has a strong correlation with OC. Other 36 sites show a very weak correlation ( $R^{2}$ : $\left.\sim 0.13\right)$ between WSON and $K^{+}$. WSON shows almost no correlation with other tracers i.e., $\mathrm{SO}_{4}{ }^{2-}, \mathrm{NO}_{3}{ }^{-}, \mathrm{Ca}^{2+}$ when data of 47 sites are considered indicating multiple sources of WSON at different sites (see Supplementary Figure S20).

Total carbon and total nitrogen ratio have been calculated with available data. In the present study, the mean total C/N ratio was $17 \pm 9$ (4-40) (see supplementary Table S7). The $\mathrm{C} / \mathrm{N}$ values are the important parameter for indicating soil or biological sources. Duan et al. (2009) reported the $\mathrm{C} / \mathrm{N}$ ratio of the order of 31.5 (14.6-57.8). They have suggested that when TSP concentrations $>400 \mu \mathrm{g} \mathrm{m}^{-3}$ and the $\mathrm{C} / \mathrm{N}$ ratios $<30$, the soil would be the important factor resulting in heavy pollution in wintertime in Beijing. In the present study, apart from 4 sites, $\mathrm{C} / \mathrm{N}$ values $<30$ for 43 sites suggests soil organics such as humic acid as important sources of WSON. Soil dust, biomass fuels burning and fossil burning are sources of nitrogen-containing aerosol in TSP.

\subsection{Major and trace elements in TSP}

Out of 27 trace species, $\mathrm{Al}$ is the most abundant species $\left(25.4 \pm 26 \mu \mathrm{g} \mathrm{m}^{-3} 26 \%\right)$ followed by $\mathrm{Ca}\left(17.7 \pm 18.3 \mu \mathrm{g} \mathrm{m}{ }^{-3}, 18 \%\right), \mathrm{Fe}\left(11.02 \pm 7.09 \mu \mathrm{g} \mathrm{m}{ }^{-3}, 11 \%\right), \mathrm{Mg}$ $\left(7.8 \pm 7.9 \mu \mathrm{g} \mathrm{m}^{-3}, 8 \%\right), \mathrm{S}\left(6.7 \pm 5.5 \mu \mathrm{g} \mathrm{m}^{-3}, 7 \%\right), \mathrm{Na}\left(6.7 \pm 5.9 \mu \mathrm{g} \mathrm{m}^{-3}, 7 \%\right), \mathrm{K}\left(5.4 \pm 5.4 \mu \mathrm{g} \mathrm{m}^{-3}, 5 \%\right), \mathrm{Cl}\left(4.8 \pm 5.1 \mu \mathrm{g} \mathrm{m}{ }^{-3}, 5 \%\right)$ in total metal concentration in TSP (Fig. 6). These 8 metal species constitute $87 \%$ of total metal concentration; whereas, the other 19 metal species constitute $13 \%$ of metal concentration in TSP (see supplementary Figure S22). The percentage contribution of trace metals is approximately $34 \%$ of TSP concentration, whereas, Kumar et al. (2015) have reported large differences in the contribution of metal species to TSP at urban sites (31\%) and open waste burning sites (8\%). Kumar et al. (2018) have reported $\mathrm{Fe}\left(8.36-46.70 \mu \mathrm{g} \mathrm{m}^{-3}\right)$ and $\mathrm{Zn}\left(2.49 \pm 0.86 \mu \mathrm{g} \mathrm{m}^{-3}\right)$ as the most abundant metals in TSP. The maximum concentration of $\mathrm{Al}\left(110.04 \mu \mathrm{g} \mathrm{m}{ }^{-3}\right)$ and $\mathrm{Ca}\left(78 \mu \mathrm{g} \mathrm{m}^{-3}\right)$ is observed at Jaunti, a maximum concentration of other two abundant metals i.e., Fe $\left(33.2 \mu \mathrm{g} \mathrm{m}^{-3}\right)$ and $\left.\mathrm{Mg} 31.19 \mu \mathrm{g} \mathrm{m}^{-3}\right)$ are noticed at Zafrabad and Karala village respectively. This indicates the spatial heterogeneity of sources of metals over Delhi. Other studies (Khemani et al. 1985; Mehra et al. 1998; Balakrishnan et al. 2000; Gadi et al. 2000; Anju and Banerjee, 2003; Srivastav et al. 2003; Khillare et al. 2004; Monkhanen et al. 2004; Srivastva and 
Jain, 2005; Yadav and Rajamani, 2006; Srivastava and Jain, 2007a, b,c, Srivastav and Jain, 2009; Rai et al. 2020) have reported concentration of metal species at few selected sites of Delhi.

The enrichment factors (EFs) determines the difference in natural (crustal) and anthropogenic sources. When $\mathrm{EF}$ is $>5$, sources are anthropogenic. The distribution pattern of EFs of metal species at 47 sites shows maximum metals are mostly of crustal origin except a few, where $\mathrm{EF}$ of $\mathrm{Zn}$, $\mathrm{Cr}$, Cu, $\mathrm{Pb}$. Co and $\mathrm{Li}$ have crossed 5 indicating other anthropogenic sources (see supplementary Figure S23 (a-b)). Among all the metal species, B shows the highest EFs at most of the sites in Delhi. Duan and Tan (2013) have summarized the major sources of some of the heavy metals ( $\mathrm{Cu}, \mathrm{Zn}, \mathrm{Cr}$, Pb, etc) in ambient air. Sharma et al. (2020) have reported a similar pattern at a station in central Delhi. In the present study, $\mathrm{Ca}, \mathrm{Mg}, \mathrm{Ti}$, and Fe have a significant correlation with $\mathrm{Al}$ and indicate mineral dust as the major source. Ca shows a good correlation with $\mathrm{Al}\left(R^{2}=0.92\right)$ indicating crustal dust as the dominant source in the particulate matter. The significant linear correlation of Al with Fe $\left(R^{2}=0.92\right)$, Al with $\mathrm{Ti}\left(R^{2}=0.49\right)$, and Al with $\mathrm{Mg}\left(R^{2}=0.95\right)$ indicated the dominant source of mineral dust in Delhi (see supplementary Figure S24).

For the first time, a high enrichment factor of Li (16.5) at Aram Bagh is reported. Very large usage of Lithium batteries in e-vehicles in Delhi might have triggered high enrichment in ambient air. Zhang and Zhou (2013) have reported electrolyte degradation, Li dendrite formation, and parasitic reactions with $\mathrm{H}_{2} \mathrm{O}$ and $\mathrm{CO}_{2}$ which are all directly correlated to reversibility and cycleability of Li-air batteries when they are operated in ambient air. The lifetime of Li-air cell has sustained repeated cycling in ambient air for 100 cycles i.e., 78 days. A very low concentration of Li $\left(0.5-42.3 \mathrm{ng} \mathrm{m}^{-3}\right.$, average: $\left.14.8 \pm 12.0 \mathrm{ng} \mathrm{m}^{-3}\right)$ is reported over Delhi with the highest value at Aram Bagh.

Xia and Gao (2011) have reported sources of Cu are vehicle emission and smelting furnace burning. High EF is noticed at Aram Bagh (8.5), Jhilmil Colony (13.2), and Govindpuri (6.2), due to anthropogenic activities like heavy vehicular emission, construction activities (Govindpuri), industrial activities (Jhilmil colony), and traffic congestion, open waste burning (Aram Bagh)

Steel, plastics and pigments production (Li et al. 2012), contaminated soil (Sun et al. 2009), coal-fired boiler and furnace burning (Tian et al. 2010) and lead gasoline (Yang et al. 2003) are reported as sources of $\mathrm{Pb}$. High EF of $\mathrm{Pb}$ only noticed at Jhilmil Colony, where industrial activities could be a source of $\mathrm{Pb}$. Several steps have been taken in removing $\mathrm{Pb}$ in gasoline. Low concentration of $\mathrm{Pb}\left(0.02-2.60 \mu \mathrm{g} \mathrm{m}^{-3}\right.$, average: $\left.0.26 \pm 0.41 \mu \mathrm{g} \mathrm{m}{ }^{-3}\right)$ as noticed over Delhi might be due to lower vehicular emission.

Waste incineration (Hopke et al. 1991; Christiamn et al. 2010; Font et al. 2015), vehicle emission and fly ash from coal-burning (Chow et al. 2004), Lubricating oil (Aucelio et al. 2007, Bukowiecki et al. 2009; Matawale et al. 2009; Pant et al. 2017), steel smelting (Querol et al. 2006), Rubber tire wear (Yang et al. 2003) are reported as sources of $\mathrm{Zn}$. In the present study, $\mathrm{Zn}$ concentration over Delhi has varied from 0.07 to $6.84 \mu \mathrm{g} \mathrm{m}^{-3}$ (average: $1.36 \pm 1.46 \mu \mathrm{g} \mathrm{m}{ }^{-3}$ ). The highest concentration is noticed at Punjabi Bagh $\left(6.84 \mu \mathrm{g} \mathrm{m}^{-3}, \mathrm{EF}: 6.84\right)$ followed by Rana Pratap Bagh $\left(3.57 \mu \mathrm{g} \mathrm{m}^{-3}, \mathrm{EF}: 7.9\right)$ and Bhogal $\left(1.49 \mu \mathrm{g} \mathrm{m}{ }^{-3}\right.$, EF: 9.7). These three sites (Punjabi Bagh: congested area, heavy vehicular emission, soil dust, Open waste burning; Bhogal: construction activities, Punjabi Bagh: vehicular emission) are characterized by anthropogenic activities. Kumar et al. (2018) have reported $\mathrm{Zn}$ concentration of the order of $2.49 \pm 0.863 \mu \mathrm{g} \mathrm{m}^{-3}$ at the NPL site and1.60 $\pm 0.589 \mu \mathrm{g} \mathrm{m}^{-3}$ and attributed it to the influence of open waste burning. Li et al. (2014) have reported lower concentration with $2.1 \pm 1.3$ $\mu \mathrm{g} \mathrm{m}^{-3}$ in winter as compared to the annual mean $\left(4.67 \pm 3.30 \mu \mathrm{g} \mathrm{m}^{-3}\right)$.

Coal and oil combustion (Tian et al. 2010; Pacyna et al. 2007) and waste incineration residue (Astrup et al. 2005; Pacyna et al. 2007; Font et al. 2015), paints, and the number of metalworking plants (Astrup et al. 2005; Unceta et al. 2010; Font et al. 2015) could be possible sources of Cr. In the present study, spatial variation of $\mathrm{Cr}$ concentration ranges from 0.06 to $6.41 \mu \mathrm{g} \mathrm{m}^{-3}$ (average: $1.26 \pm 1.36 \mu \mathrm{g} \mathrm{m}^{-3}$ ) over Delhi. Kumar et al. (2018) have reported a lower concentration of $0.27 \pm 0.07 \mu \mathrm{g} \mathrm{m}^{-3}$ at the NPL site and $0.14 \pm 0.06 \mu \mathrm{g} \mathrm{m}^{-3}$ at the Hospital site of Delhi in winter. Several sites of Delhi (Bhogal: 22.65 , Rana Pratap Bagh: 18.7, Punjabi Bagh: 13.55, Jhilmil colony: 11.2, Nizampur village: 6.22, Ranhola and Neelwal village: 5.7) show EF of Cr higher than 5 attributing the anthropogenic activities as sources of $\mathrm{Cr}$ (see supplementary Fig. 23a). The most common sources of all these sources are vehicular emission, biomass burning, open waste burning, and industrial activities. Using the above discussion, it can be identified that crustal dust, biomass burning, and fossil fuels burning are possible sources of major and trace metals in TSP.

Mass closer for geological minerals (Al, K, Ca, Ti, Fe) analyzed by ED-XRF and trace elements (Na, Mg, P, S, K by ED-XRF and Zn, Cr, Mn, Cu, Cd, Pb, Co, Ni, Bi, Li, $\mathrm{Sr}$, Ga by ICP-OES) accounted for $13.9 \%$ and $4.2 \%$ of TSP. These represent mineral oxides and metal oxides. The reconstructed mass of measured species is found around $69 \%$. The remaining unidentified mass (32\%) possibly present as water, particle-bound water, insoluble acids, etc (see supplementary Figure S4).

\subsection{Total Polycyclic Aromatic Hydrocarbons ( $\left.\sum \mathrm{PAH}\right)$ in TSP}

PAHs form a very small fraction of TSP but are categorized as more carcinogenic in comparison to other components in particulate matter. The average concentration of 16 PAHs ranged from 122 to $625 \mathrm{ng} \mathrm{m}^{-3}$ over Delhi (Table 1). The highest concentration of PAHs was observed at Udhognagar metro (E6, $625 \mathrm{ng} \mathrm{m}^{-3}$ ) followed by Bakhtawarpur (B8, $577 \mathrm{ng} \mathrm{m}^{-3}$ ); Dakshinpur Tigri (H8, $571 \mathrm{ng} \mathrm{m}^{-3}$ ); Mandawali (F10, $553 \mathrm{ng} \mathrm{m}^{-3}$ ); Block C, Sultanpuri (D6, $553 \mathrm{ng}^{-3}$ $\left.\mathrm{m}^{-3}\right)$; Surakhpur village (F3, $534 \mathrm{ng} \mathrm{m}^{-3}$ ); Nizampur village (D4, $\left.525 \mathrm{ng} \mathrm{m}^{-3}\right)$;Hamidpur (B7, $\left.510 \mathrm{ng} \mathrm{m}^{-3}\right)$. The Low values of PAHs were found at Kalkaji (F8 grid), Pandwalakhurd village (G5 grid), and Jhilmilcolony (E11 grid) over Delhi. The mean TPAHs for Delhi of all the sites were found $400 \pm 118 \mathrm{ng} \mathrm{m}^{-3}$. TPAH to TSP ratio ranged from 3 to $8 \%$. 
Table 1

Statistical summary of $16 \mathrm{PAH}$ compounds concentration in $\mathrm{ng} \mathrm{m}^{-}$

${ }^{3}$ over Delhi during January-February, 2019

\begin{tabular}{|llll|}
\hline Compound & Minimum & Maximum & Mean \\
\hline Naphthalene & 2.29 & 10.79 & $5.63 \pm 2$ \\
\hline Acenaphthylene & 1.39 & 7.81 & $3.32 \pm 2$ \\
\hline Acenaphthene & 1.32 & 60.59 & $28.56 \pm 19$ \\
\hline Fluorene & 1.03 & 47.4 & $19.50 \pm 13$ \\
\hline Phenanthrene & 1.14 & 60.2 & $15.62 \pm 17$ \\
\hline Anthracene & 1.31 & 46.17 & $8.84 \pm 11$ \\
\hline Fluoranthene & 1.59 & 42.83 & $10.19 \pm 9$ \\
\hline Pyrene & 2.38 & 38.18 & $18.17 \pm 10$ \\
\hline Benzo[a]Anthracene & 2.46 & 40.77 & $18.53 \pm 8$ \\
\hline Chrysene & 1.06 & 57.89 & $16.44 \pm 15$ \\
\hline Benzo[b]Fluoranthene & 1.65 & 46.81 & $14.04 \pm 11$ \\
\hline Benzo[k]Fluoranthene & 3.16 & 83 & $27.99 \pm 19$ \\
\hline Benzo[a]Pyrene & 5.04 & 130.01 & $40.27 \pm 29$ \\
\hline Dibenzo[ah]Anthracene & 4.97 & 115.11 & $44.67 \pm 29$ \\
\hline Benzo[ghi]Perylene & 6.41 & 155.28 & $49.96 \pm 39$ \\
\hline Indeno[123-cd]Pyrene & 6.75 & 169.13 & $78.32 \pm 43$ \\
\hline
\end{tabular}

The highest concentration of PAHs can be found in the urban area due to high vehicular activities and less dispersion of pollutants (Sharma et al. 2006). The average concentration of PAHs was found $667.73 \pm 399.38 \mathrm{ng} \mathrm{m}^{-3}$ in Sharma et al. (2006), and they also explained that the concentration of PAHs is higher during winter than monsoon and summer. Earlier studies also revealed the same (Harsall et al. 1994; Harrison et al. 1996; Panther et al. 1999; Park et al. 2002; Guo et al. 2003). Sharma et al. (2007) have also reported high values of PAHs $\left(672 \mathrm{ng} \mathrm{m}^{-3}\right)$ ) during winter.

Incomplete combustion of organic materials is the main source of emissions of PAHs by use of wood and biomass burning, oil, coal, and gas (WHO, 2000; Wang et al. 2007; Tobiscewski and Nemishik, 2012; Alebic-Juretic, 2015). Identified PAHs are further classified into four classes based on their aromatic ring structure, 2-3 rings, 4 rings, 5 rings, and 6 rings. Five rings PAHs had contributed $52 \%$ to total PAHs concentration followed by six rings ( $42 \%$ ), four rings (4\%), and two three rings (2\%), respectively over Delhi sampling locations (Fig. 7). It is clear from these values that 5-6 rings PAHs, which are considered to be carcinogenic, are dominant over the Delhi region.

High molecular weight compounds are more persistent and less volatile and can travel a long distance than other lower molecular weight compounds. Out of 16 PAHs, Benzo[a]Pyrene, Dibenzo[ah]Anthracene, Benzo[ghi]Perylene, and Indeno[123-cd]Pyrene had the highest concentrations with a minimum and maximum of 5-130 $\mathrm{ng} \mathrm{m}^{-3}, 4.9-115.1 \mathrm{ng} \mathrm{m}^{-3}, 6.4-155.3 \mathrm{ng} \mathrm{m}^{-3}$ and $6.7-169 \mathrm{ng} \mathrm{m}^{-3}$ respectively (Table 2). Observance of the highest concentration of high molecular weight PAHs corroborated that carcinogenic PAHs were dominant in Delhi. 5-6 rings. PAHs present in the least concentration were Naphthalene and Acenaphthylene and their minimum and maximum ranges were $2.3-10.8 \mathrm{ng} \mathrm{m}^{-3}$ and $1.4-7.8 \mathrm{ng} \mathrm{m}^{-3}$, respectively. 
Table 2

Diagnostic ratios of PAHs present in ambient air of Delhi.

\begin{tabular}{|c|c|c|c|c|}
\hline \multirow[b]{2}{*}{ Diagnostic ratio } & \multirow{2}{*}{ Present study } & \\
\hline & & Value & Sources & References \\
\hline \multirow[t]{2}{*}{ IP/ (IP + BghiP) } & \multirow[t]{2}{*}{0.61} & $0.20-0.50$ & Fuel combustion & Tobiszewski and Namiesnik (2012) \\
\hline & & $>0.50$ & Coal and biomass combustion & Kavuoras et al. (1999) \\
\hline \multirow[t]{2}{*}{$\mathrm{BaP} /(\mathrm{BaP}+$ Chy $)$} & \multirow[t]{2}{*}{0.71} & 0.73 & Gasoline & Shivani et al. (2018) \\
\hline & & $>0.35$ & Traffic emissions & Yunker et al. (2002) \\
\hline \multirow[t]{2}{*}{ IP/BghiP } & \multirow[t]{2}{*}{1.57} & 1 & Diesel engine & Shivani et al. (2018) \\
\hline & & $0.27-0.4$ & Gasoline engine & Caricchia et al. (1999) \\
\hline \multirow[t]{2}{*}{ Phth/(Phth + Anth) } & \multirow[t]{2}{*}{0.64} & $<0.7$ & Biomass burning & Kavuoras et al. (1999) \\
\hline & & $>0.7$ & Fossil fuels & \\
\hline \multirow[t]{2}{*}{ BaP/BghiP } & \multirow[t]{2}{*}{0.81} & $<0.6$ & Non traffic & Pandey et al. (1999) \\
\hline & & $>0.6$ & Traffic & \\
\hline
\end{tabular}

For the identification of possible pollution sources of PAHs in the atmosphere, the molecular diagnostic ratios (MDRs) were calculated and compared with values available in the literature. In this study, for source identification, we have considered five major molecular diagnostic ratios i.e., IP/(IP + BghiP),

$\mathrm{BaP} /(\mathrm{BaP}+\mathrm{Chy})$, Phth (Phth + Anth), BaP/BghiP, and IP/BghiP (Table 2). All the diagnostic molecular ratios are indicative of different PAH origin sources. The benzopyrenes, chrysene are the major PAHs compounds associated with combustion sources (Kavouras et al.1999). The mean IP/ (IP + BghiP) ratio (0.6 \pm 0.2 ) strongly indicates coal and wood combustion sources. The $\mathrm{BaP} /(\mathrm{BaP}+\mathrm{Chy})$ ratio $(0.7 \pm 0.2)$ indicates that PAHs are also derived from gasoline emissions. The IP/BghiP ratio $(1.6 \pm 0.9)$ shows that diesel emissions were dominant. The Phth/(Phth + Anth) ratio differentiates between biomass burning and fossil fuel emissions. The higher Phth/(Phth + Anth) ratio $(0.6 \pm 0.2)$ indicates biomass burning. This may be due to the biofuels burning in the villages and slum areas. The BaP/BghiP ratio $(0.8 \pm 0.2)$ indicates that PAHs are from traffic emissions. These source diagnostic ratios conveyed that PAHs have both vehicular as well as biomass burning emissions as dominant sources. Gadi et al. (2019) and Shivani et al. (2019) have reported similar results for fine ambient aerosols.

In a nutshell, qualitatively it can be said that different types of sources i.e., soil dust, biomass burning, fossil fuels burning (industrial activities, vehicular emission, open waste burning, etc), secondary organic and inorganic formation have contributed to spatial variation in TSP concentration over Delhi based on their strength. For quantitative identification, more robust statistical analysis is required. In the present study, PCA has been performed using measured TSP concentration, and its chemical properties.

\subsection{Source apportionment of TSP}

\subsubsection{PCA of organic, inorganic, and trace elements of TSP}

To understand and identify the possible sources of TSP, PCA was performed for chemical constituents of TSP (Mg, Fe, K, Al, Na, Cl, Ca, Ti, Zn, $\mathrm{Sr}, \mathrm{Ni}, \mathrm{Pb}, \mathrm{Cu}, \mathrm{Bi}$, $\mathrm{Li}, \mathrm{Cr}, \mathrm{Co}, \mathrm{Cd} \mathrm{SO}_{4}{ }^{2-}, \mathrm{NO}_{3}{ }^{-}, \mathrm{NH}_{4}{ }^{+}, \mathrm{OC}, \mathrm{EC}$, and WSOC) by the varimax rotated factor matrix method of SPSS statistics viewer. $24 \mathrm{TSP}$ constituents were used as variables in the dataset (Table 3) and some components ( $\mathrm{P}, \mathrm{S}, \mathrm{B}, \mathrm{Ag}, \mathrm{Pd}, \mathrm{Ga}, \mathrm{F}, \mathrm{As}, \mathrm{NO}_{2}{ }^{-}$) were excluded. Six components were extracted as principal components that have $82.1 \%$ of the total variance of the data. Principle components to be retained were decided by examining the screen plot and percent of the variance. PCs that have eigenvalue > 1 divide the data into groups and were considered for further analysis for source identification (Hazarilka et al. 2015; Shivani et al. 2018). 
Table 3

PCA for TSP collected during winter in Delhi

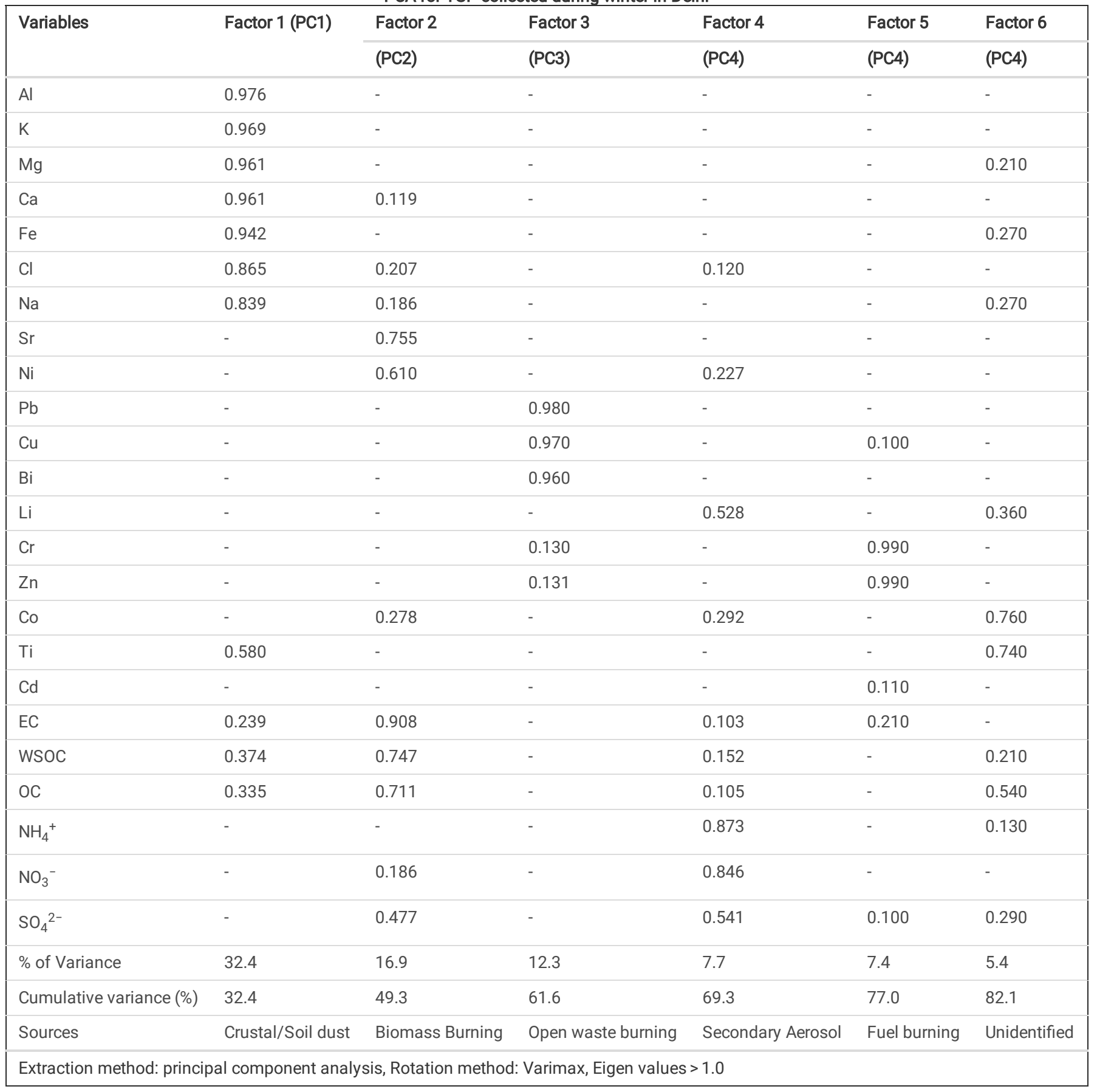

Factor 1 (PC1) contained high loading of $\mathrm{Mg}, \mathrm{Fe}, \mathrm{K}, \mathrm{Al}, \mathrm{Na}, \mathrm{Cl}, \mathrm{Ca}, \mathrm{Ti}$, and $\mathrm{OC}$ with $32.4 \%$ of variance which indicates the major contribution of crustal/soil dust as these are soil-related crustal elements (Jain et al. 2017; Srivastava and Jain. 2007a; Pant and Harrison. 2012; Hazarika et al. 2015) and occurrence of Fe with OC marked for road dust (Banerjee et al. 2015). Crustal/soil re-suspension plays a major role in elemental profile for coarse as well as in fine particles. In the winter season, soil dust and mining effect is the most dominant source in coarse particles like TSP due to the temperature inversion effect (Hazarika et al. 2015). Emissions of some of the elements such as $\mathrm{Na}, \mathrm{Cl}, \mathrm{K}, \mathrm{Al}$, and $\mathrm{Zn}$ were also linked with other anthropogenic activities (re-suspension of soil particles, vehicular emissions, and metals used in industrial activities) (Hazarika et al. 2016).

In Factor 2 (PC2) source was identified with high loading of OC, WSOC, and EC attributed to biomass burning with $16.9 \%$ of the variance. EC is marked extensively for combustion sources and also indicates minor chemical transformations (Song et al. 2006; Yin et al. 2010). On the other hand, OC is emitted directly from primary emission sources i.e. combustion and vaporization of solvent (Turpin and Huntzicker, 1991; Ho et al. 2003; Behera and Sharma, 2010). Factor 3 (PC3) accounted for $12.3 \%$ of total variance with high loading of $\mathrm{Pb}, \mathrm{Zn}, \mathrm{Bi}, \mathrm{Cr}$ with $\mathrm{Cu}$ indicating open waste burning, and $\mathrm{Cu}, \mathrm{Pb}$, and $\mathrm{Zn}$ are responsible for non-ferrous metal operations (Arditsoglou et al. 2005). Factor 4 (PC4) is responsible for $7.7 \%$ of total variance contained high loading of $\mathrm{NO}_{3}{ }^{-}$, $\mathrm{SO}_{4}{ }^{2-}$ and $\mathrm{NH}_{4}{ }^{+}$which indicates secondary inorganic aerosol (high loading of secondary nitrate and secondary sulphate). The product of secondary inorganic aerosol formed in the atmosphere can be emitted by natural or anthropogenic sources (Jain et al. 2020). Precursors of secondary $\mathrm{NO}_{3}{ }^{-}$is nitric oxide ( $\mathrm{NO}$ ) 
which is generated as a result of high-temperature combustion (Khan et al. 2010; Sharma et al. 2020). Factor 5 (PC5) is dominated by Cr and Zn with EC indicated the significant contribution to fuel-burning/vehicle exhaust and it explained with $7.4 \%$ of the variance (Srivastava et al. 2005). Factor 6 (PC6) responsible for $5.4 \%$ of total variance with high loading of $\mathrm{Co}, \mathrm{Ti}$, and $\mathrm{OC}$ which is difficult to be explained and is assigned as unidentified. For a better understanding of possible sources in the mixed contribution, PCA was also performed for polar organics.

\subsubsection{PCA of polar organics}

PCA was performed for combined data of OC, EC, and 16 PAHs to identify major possible sources. 16 PAHs, OC, and EC constituents were used as variables in this data set. Table 4 summarizes the output of PCA for organics in TSP during winter over Delhi. PC1 has explained a total of $14 \%$ of the variance with high loading of Acth(82\%), $\mathrm{Fl}(52 \%)$, $\mathrm{Nph}(37 \%)$, IP(36\%) which indicated the emission of PAHs from biomass burning in the ambient atmosphere (Shivani et al. 2019). PC2 has contained high loading of pyr $(64 \%), \mathrm{BaF}(56 \%), \mathrm{BaP}(64 \%)$ with $12 \%$ of total variance. The dominance of these PAHs indicated the contribution of secondary organic carbon, vehicular activities (diesel dominated), and coal-burning to a high level over Delhi (Agarwal et al. 2009; Gupta et al. 2011). PC3 has contained high loading of Phth(84\%), Flth(61\%), BaA, Chy with $12 \%$ of the total variance and suggested the contribution from plastic and waste burning to observed PAHs over Delhi. Simoneit et al. (2005) also accounted for the contribution of open burning of roadside litter and landfill trash for total PAHs emissions. PC4 witnessed high loading of EC (80\%), OC (78\%), BkF, BbF with $12 \%$ of total variance which indicates the contribution of vehicular emissions and biofuel combustion (Guo et al. 2003; Fang et al. 2004; Gupta et al. 2011; Masih et al. 2012). BkF dominance indicated the emissions from the diesel vehicles relative to other PAHs (Venkataraman et al. 1994; Randolph and Joel, 2003). The factor dominated by EC shows fossil fuel burning/ vehicle exhaust emissions (Shivani et al. 2019). PC5 explained high loading of $\mathrm{DahA}(80 \%), \mathrm{BghiP}(78 \%), \mathrm{BaA}(12 \%), \mathrm{BkF}(13 \%)$ with $8 \%$ of total variance which indicates the contribution of cooking emissions, coal combustion, and vehicular emissions (Harrison et al. 1996; Randolph and Joel, 2003; Gupta et al. 2011; Sarkar and Khillare, 2010). PC6 showed high loading of Acy (77\%), FI (23\%), Anth (13\%) with 8\% of total variance indicating space heating as the major reason. Space heating included the burning of wood and cow dung. Hazarika et al., (2015) have reported that the coal tar use in ongoing road repairing activity, could be responsible for emissions of PAHs. In nutshell, it can be considered that biomass burning (fuelwood and cow dung), secondary inorganic aerosol, vehicular emissions, plastic, and waste burning, cooking emissions and coal combustion are the major emission sources of PAHs in the winter season over Delhi.

Table 4

PCA for organics in TSP collected during winter over Delhi

\begin{tabular}{|c|c|c|c|c|c|c|}
\hline Variables & Factor 1 (PC1) & Factor 2(PC2) & Factor 3(PC3) & Factor 4(PC4) & Factor 5(PC5) & $\begin{array}{l}\text { Factor } \\
\text { 6(PC6) }\end{array}$ \\
\hline Acenaphthene & 0.821 & 0.339 & & & & \\
\hline Anthracene & & 0.31 & & & & 0.135 \\
\hline Fluorene & 0.586 & 0.263 & 0.372 & & & 0.233 \\
\hline Chrysene & & 0.13 & 0.414 & & & \\
\hline Benzo[k]Fluoranthene & 0.11 & 0.706 & & 0.257 & 0.139 & \\
\hline Pyrene & & 0.648 & 0.409 & 0.111 & & \\
\hline Benzo[a]Pyrene & & 0.642 & & & & 0.331 \\
\hline Benzo[b]Fluoranthene & & 0.565 & 0.318 & 0.164 & & \\
\hline Phenanthrene & & & 0.838 & 0.111 & 0.139 & \\
\hline Fluoranthene & & 0.117 & 0.617 & 0.217 & & 0.332 \\
\hline Benzo[a]Anthracene & 0.116 & 0.401 & 0.549 & & 0.127 & 0.127 \\
\hline $\mathrm{EC}(\mu \mathrm{g} / \mathrm{m} 3)$ & 0.108 & 0.196 & 0.138 & 0.791 & & \\
\hline $\mathrm{OC}(\mu \mathrm{g} / \mathrm{m} 3)$ & 0.118 & 0.126 & 0.311 & 0.773 & & 0.407 \\
\hline Indeno[123-cd]Pyrene & 0.366 & 0.212 & 0.196 & & 0.185 & \\
\hline Dibenzo[ah]Anthracene & 0.142 & & & & 0.800 & \\
\hline Benzo[ghi]Perylene & & & & & 0.783 & \\
\hline Acenaphthylene & & & & 0.22 & 0.151 & 0.772 \\
\hline Naphthalene & 0.374 & & 0.145 & & & 0.652 \\
\hline$\%$ of Variance & 14.49 & 12.55 & 12.10 & 12.00 & 8.58 & 8.52 \\
\hline Cumulative \% & 14.49 & 27.05 & 39.16 & 51.16 & 59.75 & 68.27 \\
\hline Sources & $\begin{array}{l}\text { Biomass } \\
\text { Burning }\end{array}$ & $\begin{array}{l}\text { Secondary Organic } \\
\text { Carbon }\end{array}$ & $\begin{array}{l}\text { Plastic and Waste } \\
\text { Burning }\end{array}$ & $\begin{array}{l}\text { Vehicular } \\
\text { Emissions }\end{array}$ & $\begin{array}{l}\text { Cooking } \\
\text { emissions }\end{array}$ & $\begin{array}{l}\text { Room } \\
\text { Heating }\end{array}$ \\
\hline
\end{tabular}




\section{Conclusion}

Large variations of TSP at 47 sites of Delhi measured during winter (January-February 2019) suggest the variation in sources types and their strength. The chemical analysis (OC, EC, WSOC, TN, WSIS, and PAHs) of TSP and a robust statistical analysis (PCA) have provided the following qualitative and quantitative location-specific information of sources as given below:

- The maximum concentration of OC, EC, and WSOC was observed at Rana Pratap Bagh, a site of highest TSP. OC/EC ratio and good correlation between OC and EC suggest that sources are common and the mixture of biomass burning and fossil fuel burning. WSOC contributes $29 \%$ to OC and a lower WSOC/OC ratio indicates the role of advected aged aerosols in addition to local sources. In contrast, a higher WSOC/OC ratio (0.51) at Majnu Ki Tila, a tourist bus stand suggests the photochemical activity of freshly released organic compounds and possible formation of SOA. Delhi being a megacity, vehicular emission might have contributed to fossil fuel combustion.

- Primary WSIS $\left(\mathrm{Cl}^{-}+\mathrm{Na}^{+}+\mathrm{K}^{+}+\mathrm{Ca}^{+2}+\mathrm{Mg}^{+2}+\mathrm{F}^{-}\right)$contribute $67 \%$ to WSIS with maximum concentration at Rana Pratap $\mathrm{Bagh} \mathrm{Cl}^{-} / \mathrm{Na}^{+}$ratio, $\mathrm{K}^{+} / \mathrm{Na}^{+}, \mathrm{Mg}^{+} / \mathrm{Na}^{+}$ ratios rule out the presence of sea salt at the study sites and suggesting the role of biomass burning, open waste burning, and industrial emission. Secondary WSIS $\left(\mathrm{SO}_{4}{ }^{2-}+\mathrm{NO}_{3}{ }^{-}+\mathrm{NO}_{2}{ }^{-}+\mathrm{NH}_{4}{ }^{+}+\mathrm{PO}_{4}{ }^{3-}\right)$ contributes $33 \%$ to WSIS attributing lesser role of secondary inorganic formation. Minimum concentration was observed in southeast and southwest Delhi. Unprecedented higher concentration of $\mathrm{Cl}^{-}$all over Delhi suggests possible roles of plastic burning, municipality waste burning, and industry emission.

- Nitrogen components contribute $2-3 \%$ of TSP, the highest concentration of WSIN and WSON was observed at Rawta Mor (21.7 $\mu$ g $\mathrm{m}^{-3}$ ) and Majnu Ka Tila $\left(21.6 \mu \mathrm{g} \mathrm{m}^{-3}\right)$, situated on the highway with heavy traffic load in Delhi respectively. The highest WSOC concentration was also observed at Majnu Ki Tila and strongly supports the hypothesis of SOA formation. A stronger significant correlation (0.65) is observed between WSON and OC at 13 sites of Delhi when WSON/OC is within the range of $0.10-0.20$ attributing the sources of WSON and OC are common. When C/N ratio $<30$ and TSP $>400 \mu \mathrm{g} \mathrm{m}^{-3}$ then crustal soil is one of the sources. Out of 47 sites, 41 sites indicate the contribution of crustal to TSP.

- Out of 27 trace metal species, Al is the most abundant species followed by $\mathrm{Ca}, \mathrm{Fe}, \mathrm{Mg}, \mathrm{S}, \mathrm{Na}, \mathrm{K}, \mathrm{Cl}$ in TSP. The enrichment factors (EFs) determine the difference in natural (crustal) and anthropogenic sources. When EFs are $>5$, sources are anthropogenic. The distribution pattern of EF of metal species at 47 sites shows that maximum species are of crustal origin except a few $(\mathrm{Zn}, \mathrm{Cr}, \mathrm{Cu}, \mathrm{Pb}$. Co, and $\mathrm{Li})$ which have crossed 5 indicating other anthropogenic sources. Most sources are due to vehicular emissions. The significant linear correlation of $\mathrm{Al}$ with $\mathrm{Fe}\left(R^{2}=0.92\right), \mathrm{Al}$ with $\mathrm{Ti}\left(R^{2}=0.49\right)$, and $\mathrm{Al}$ with $\mathrm{Mg}\left(R^{2}\right.$ $=0.95)$ indicated the dominant source of mineral dust in Delhi.

- Dominating species of PAHs are (Benzo[a]Pyrene, Dibenzo[ah]Anthracene, Benzo[ghi]Perylene) with a minimum-maximum range of (5-130 ng $\mathrm{m}^{-3}$ ), (4.9$115.1 \mathrm{ng} \mathrm{m}^{-3}$ ), and (6.4-155.3 $\mathrm{ng} \mathrm{m}^{-3}$ ). High molecular weight compounds (5 rings and 6 rings) were observed at Udhognagar metro (240 $\mathrm{ng} \mathrm{m}^{-3}$ and $299 \mathrm{ng} \mathrm{m}^{-3}$ ) due to high combustion activities and plastic factories around the location and these species are highly dangerous even in nanogram quantity.

- The analysis obtains the mass closer to approximately $68 \%$ of the total suspended particulates which determined the estimated sources: Inorganics $(25 \%)$, salts ( $9 \%)$, geological minerals (11\%), trace elements (5\%), a sum of organic matter-EC (18\%). The unidentified mass is about $31 \%$ which cannot be measured. OM represented the presence of biomass burning (cooking, space heating, and waste burning), exhaust gases, oil refineries. During the winter period (study period) formation of secondary reactions is enhanced which contributed to inorganic ions.

- In a nutshell, qualitatively it can be said that different types of sources i.e., soil dust, biomass burning, fossil fuels burning (industrial activities, vehicular emission, open waste burning, etc), secondary organic and inorganic formation have contributed to spatial variation in TSP concentration over Delhi based on their strength. For quantitative identification, more robust statistical analysis is required. In the present study, PCA has been performed using measured TSP concentration, and its chemical properties.

- PCA was performed for 24 constituents of TSP which identified four principal components with $82.1 \%$ of the total variance of the data. Soil dust/crustal with $32.38 \%$ of variance indicated major contribution followed by biomass burning (16.9\%). Further analysis of PCA performed for the clarification of mixed sources, identified six principle components with $68 \%$ variance with biomass burning (14\%), secondary organic carbon (12.5\%), plastic and waste burning (12\%), vehicular emissions (12\%), cooking emissions (8.5\%), room heating ( $8.5 \%)$ are the major contributors over Delhi.

Our spatial gridded distribution of TSP concentration is among the first available with its chemical composition estimation. The significant outcome of this study is the identification of variation in source contribution at $5 \times 5 \mathrm{~km}^{2}$ grids covering entire Delhi including rural and urban regions. Trajectory analysis suggests that apart from local sources, long-range transport from Haryana and Punjab carried along with the north-eastern low-level flow to the receptor sites could be another source during the winter.

\section{Declarations}

\section{Acknowledgment}

The authors are thankful to Director, CSIR-NPL, New Delhi, and Head, Environmental Sciences and Biomedical Metrology Division, CSIR-NPL, New Delhi, India for their constant encouragement and support. The authors are also thankful to the Ministry of Earth Sciences for the financial support (MoES/16/19/2017$\mathrm{APHH}$ ) (DelhiFlux).

\section{Ethics approval and consent to participate}

Not applicable

\section{Consent for publication}


Not applicable

\section{Availability of data and materials}

All data generated or analyzed during this study are included in this published article and its supplementary information files

\section{Competing interests}

The authors declare that they have no competing interests

\section{Author contribution}

RJ has collected samples, done chemical analysis of organics, WSOC, metal using ED-XRF, and lead in the manuscript preparation. SA has collected samples and done chemical analysis of organics, WSOC, nitrogen component, and prepared extraction for lons. GK, RA, AM, LY, PY, NC, MR, RB, AR, USS have collected samples over Delhi and contributed to the manuscript. NR and AP have assisted in WSOC and TN and contributed to the manuscript. Shivani and RG have assisted in the analysis of PAH and contributed to the manuscript. PS has analyzed metal using ICP-OEC and contributed to the manuscript. NV has assisted in metal analysis using ED-XRF and contributed to the manuscript. CS has contributed to the Manuscript. SKS has analyzed OC, EC data and performed PCA and contributed to draft the manuscript. TKM has given conception and design of the study, guidance, analyses the WSIS data, and contributed to draft the manuscript. All the authors read and approved the final manuscript.

\section{Funding}

No funding.

\section{References}

Agarwal T, Khillare, PS, Shridhar V, and Ray S (2009) Pattern, sources and toxic potential of PAHs in the agricultural soils of Delhi, India. J Hazardous Materials 163(2):1033-1039

Agnihotri R, Mandal TK, Karapurkar S, Naja M, Gadi R, Ahammmed YN, Kumar A, Saud T, and Saxena M (2011) Stable carbon and nitrogen isotopic composition of bulk aerosols over India and northern Indian Ocean. Atmos Environ 45(17):2828-2835

Air Quality Monitoring Network, (2008) National ambient air quality status, CPCB, SERIES: NAAQMS//2009-10. http://www.indiaenvironmentportal.org.in/files/Air-Report-2008.pdf

Alebić-Juretić A, (2015) Airborne Polycyclic Aromatic Hydrocarbons in Suspended Particulates from the Urban Atmosphere of Rijeka, Croatia. Polycyclic Aromatic Compounds 35(1):91-101

Aucélio RO, De Souza RM, De Campos RC, Miekeley N, Porto da Silveira CL (2007) The determination of trace metals in lubricating oils by atomic spectrometry. Spectrochimica Acta Part B, 62: 952-961

ATSDR (2011) Case Studies in Environmental Medicine. Toxicity of Polycyclic Aromatic Hydrocarbons

Anju and Banerjee DK, (2003) Heavy metal levels and solid phase speciation in street dusts of Delhi. India. Environ Poll 123:95-105.Astrup T, Rosenblad C, Trapp S. and Christensen TH (2005). Chromium release from waste incineration air pollution-control residues. Environ Sci Technol 39: 3321-3329

Arditsoglou A and Samara C, (2005) Levels of total suspended particulate matter and major trace elements in Kosovo: a source identification and apportionment study. Chemosphere 59:669-678

Baker KR, Kotchenruther RA, Hudman RC, (2016). Estimating ozone and secondary PM2.5 impacts from hypothetical single source emissions in the central and eastern United States. Atmos Pollut Res 7:122-133. https://doi.org/10.1016/j.apr.2015. 08.003

Balachandran S, Meena BR, Khillare PS (2000). Particle size distribution and its elemental composition in the ambient air of Delhi. Environ Int 26: 49-54

Banerjee T, Murari V, Kumar M, Raju MP (2015) Source apportionment of airborne particulates through receptor modelling: Indian scenario. Atmos Res $164: 167-187$

Behera SN, Sharma M, (2010) Investigating the potential role of ammonia in ion chemistry of fine particulate matter formation for an urban environment. Sci Total Environ 408(17):3569-3575

Bhowmik HS, T Naresh S, Bhattu D, Rastogi N, Prévôt ASH, Tripathib SN (2020) Temporal and spatial variability of carbonaceous species (EC; OC; WSOC and SOA) in PM2.5 aerosol over five sites of Indo-Gangetic Plain. Atmos Pollu Res https://doi.org/10.1016/j.apr.2020.09.019

Bi X, Zhang G, Li L, Wang X, Li M, Sheng G, Fu J and Zhou Z (2011) Mixing state of biomass burning particles by single particle aerosol mass spectrometer in the urban area of PRD. China. Atmos Environ 45: 3447-3453

Bikkina S, Andersson A, Kirillova E, Holmstrand H, Tiwari S, Srivastava AK, Bisht DS and Gustafsson Ö (2019) Nature Sustainability. https://doi.org/10.1038/s41893-019-0219-0 
Bisht DS, Dumka UC, Kaskaoutis DG, Pipal AS, Srivastava AK, Soni VK, Attri SD, Sateesh M and Tiwari S (2015) Carbonaceous aerosols and pollutants over Delhi urban environment: Temporal evolution, source apportionment and radiative forcing. Sci of the Total Environment, 521-522: 431-445

Bond TC and Bergstrom RW (2006) Light absorption by carbonaceous particles An investigative review. Aer Sci Tech 40(1):27-67

Bukowiecki N, Lienemann P, Hill M, Figi R, Richard A, Furger M, Rickers K, Falkenberg G, Zhao Y, Cliff SS, Prevot ASH, UrsBaltensperger, Buchmann B, and Gehrig R (2009) Real-World Emission Factors for Antimony and Other Brake Wear Related Trace Elements: Size-Segregated Values for Light and Heavy-Duty Vehicles. Environ Sci \& Tech 43 (21):8072-8078

Cauer H, (1951) Some problems of atmospheric chemistry, in Compendium o] Meteorology, American Meteorological Society, Boston

Caricchia AM, Chiavarini S, Pezza M (1999) Polycyclic aromatic hydrocarbons in the urban atmospheric particulate matter in the city of Naples (Italy). Atmos Environ, $33,3731-3738$.

Chan YC, Simpson RW, Mctainsh GH, Vowles PD(1997) Characterisation of chemical species in $\mathrm{PM}_{2.5}$ and PM 10 aerosols in Brisbane, Australia. Atmos Environ 31, 22:3773-3785

Chattopadhyay S (2010) Spatial and Temporal Variation of Urban Air Quality: A GIS Approach. J of Environ Prot 1(03):264-277

Roge,r C, Morelli J, Buat-Menard P (1972) Variations in ionic ratios between reference sea water and marine aerosols. J of Geophy Res 77, 27:5116-5131

Cheung KL, Polidori A, Ntziachristos L, Tzamkiozis T, Samaras Z, Cassee FR, Gerlofs M, and Sioutas C, (2009) Chemical Characteristics and Oxidative Potential of Particulate Matter Emissions from Gasoline, Diesel, and Biodiesel Cars. Environ Sci Technol 43:6334-6340

Chow JC, Fujita EM, Watson JG, Lu Z, Lawson DR and Ashbaugh LL (1994a)Evaluation of filter-based aerosol measurements during the 1987 Southern California Air Quality Study. Environ Monit Assess 30,49-80

Chow JC, Watson JG, Fujita EM, Lu Z, Lawson DR and Ashbaugh LL (1994b) Temporal and spatial variations of PM2.5 and PM10 aerosol in the Southern California Air Quality Study. Atmos Environ 28:2061-2080

Chow JC, Watson JG, Edgerton SA and Vega E (2002a) Chemical composition of $\mathrm{PM}_{10}$ and $\mathrm{PM}_{2.5}$ in Mexico City during winter 1997 . Sci Total Environ 287:177-201

Chow JC, Watson JG, Edgerton SA, Vega E, Ortiz E (2002b) Spatial differences in outdoor PM10 mass and aerosol composition in Mexico City. J Air Waste Manage Assoc 52:423-434

Chow JC and Watson JG (2002) Review of PM2.5 and PM10 apportionment for fossil fuel combustion and other sources by the chemical mass balance receptor model. Energy Fuels 16: 222-260

Chow JC, Lowenthal DH, Chen LW, Wang X, Watson JG (2015) Mass reconstruction methods for PM 2.5 : A review. Air Qual Atmos Health 8:243-263

Christian TJ, Yokelson RJ, Cardenas B, Molina LT, Engling G, and Hsu S-C (2009) Trace gas and particle emissions from domestic and industrial biofuel use and garbage burning in central Mexico. Atmos Chem Phys 10:565-584

Christensen WF (2004) Chemical Mass Balance Analysis of Air Quality Data when Unknown Pollution Sources are Present. Atmos Environ 38:4305-4317

Collett J, Daube B, Gunz D, Hoffmann M (1990) Intensive studies of Sierra Nevada cloud water chemistry and its relationship to precursor aerosol and gas concentrations. Atmos Environ 24:1741-1757

Contini D, Cesari D, Genga A, Siciliano M, lelpo P, Guascito MR and Conte M (2013) Source apportionment of size-segregated atmospheric particles based on the major water-soluble components in Lecce (Italy). Sci Total Environ 472(15):,248-61

Cooper JA (1980) Environmental impact of residential wood combustion emissions and its implications. J Air Pollut Control Assoc 8:855-861

Cornell S, Mace K, Coeppicus S, Duce R, Huebert B, Jickells T, Zhuang L-Z, (2001) Organic nitrogen in Hawaiian rain and aerosol. J Geophysi Res, 106, 79737983

CPCB, National Ambient Air Quality Standards, Central Pollution Control Board Notification New Delhi, the 18th November, 2009

David AE, Kesiye IA, Stephen UA, Nimibofa A, and Etta BA (2017) Measurement of Total Suspended Particulate Matter (TSP) in an Urban Environment: Yenagoa and Its Environs. Journal of Geography. Environ and Earth Sci Int 11(3), 1-8:2454-7352

Dockery DW, Pope CA, Xu X, Spengler JD, Ware JH, Fay ME, Ferris Jr B G, Speizer FE (1993) An association between air pollution and mortality in six US cities. New England Journal of Medicine 329(24):1753-9

Duan JC and Tan JH (2013) Atmospheric heavy metals and arsenic in China: situation, sources and control policies Atmos Environ 74:93-101, doi:10.1016/j.atmosenv.2013.03.031, 2013 
Duan FK, Liu XD, He KB, Dong SP, (2009) Measurements and characteristics of nitrogen-containing compounds in atmospheric particulate matter in Beijing, China. Bull. Environ Contam Toxicol 82:332-337

Dumka U, Tiwari S, Kaskaoutis D, Hopke PK, Singh J, Srivastava AK, Bisht DS, Atri SD, Tyagi S, Misra A, Pasha GSM (2017) Assessment of PM 2.5 chemical compositions in Delhi: primary vs secondary emissions and contribution to light extinction coefficient and visibility degradation. J Atmos Chem 74: $423-450$.

Dumka UC, Tiwari S, Kaskaoutis DG, Soni VK, Safai PD, Attri SD, (2019) Aerosol and pollutant characteristics in Delhi during a winter research campaign. Environ Sci Pollut Res 26: 3771-3794.

Font A, Hoogh K, Leal-Sanchez M, Ashworth DC, Brown RJ, Hansell AL and Fuller GW (2015) Using metal ratios to detect emissions from municipal waste incinerators in ambient air pollution data. Atmos Environ 113: 177-186

Gadi R, Singh N, Sarkar AK, Parashar DC (2000) Mass size distribution and chemical composition of aerosols at New Delhi. In: Siddappa, K., Sadasivan, S., Sastri, V.N., Eappen, K.P., Somashekar, R.K., Manamohan Rao, N. (Eds.), Pollution in Urban Environment. Bangalore University, Bangalore, pp. $30-32$

Gadi R, Shivani, Sharma SK, Mandal TK, (2019) Source apportionment and health risk assessment of organic constituents in fine ambient aerosols ( $\mathrm{PM}_{2.5}$ ): A complete year study over National Capital Region of India. Chemosphere 221:583-596.

Goel V, Mishra SK, Ahlawat A, Kumar P, Senguttuvan TD, Sharma C, Reid JS (2020) Insights into coarse particle optics based on field evidence of particle morphology, chemical composition and internal structure. Atmospheric Environment 232: 117338

Goswami P and Baruah J, (2008) Simulation of Daily Variation of Suspended Particulate Matter over Delhi: Relative Roles of Vehicular Emission, Dust, and Domestic Appliances, Monthly Weather Review. Pp- 3597-3607 DOI: 10.1175/2008MWR2386.1

Goyal, P and Sidharth, (2003) Present scenario of air quality in Delhi: a case study of CNG implementation. Atmos Environ 37: $5423-5431$

Gunthe, S.S., Liu, P., Panda, U. et al. (2021), Enhanced aerosol particle growth sustained by high continental chlorine emission in India. Nat. Geosci. 14, 77-84 https://doi.org/10.1038/s41561-020-00677-x

Guo H, Lee SC, Ho KF, Wang XM, Zou SC (2003) Particle associated polycyclic aromatic hydrocarbons in urban air of Hong Kong. Atmos. Environ, 37:53075317

Gupta S, Gadi R, Sharma SK, Mandal TK (2018) Characterization and source apportionment of organic compounds in PM10 using PCA and PMF at a traffic hotspot of Delhi. Sustain Cities Soc 39: 52-67

Gupta S, Kumar K, Srivastava A, Jain VK (2011) Size distribution and source apportionment of polycyclic aromatic hydrocarbons (PAHs) in aerosol particle samples from the atmospheric environment of Delhi, India. Sci Total Environ409: 4674-4680

Gurjar BR, Aardenne JA, Lelieveld J, Mohan M (2004) Emission estimates and trends (1990-2000) for megacity Delhi and implications. Atmos Environ 38:5663-5681.

Guttikunda SK, Gurjar BR (2012) Role of meteorology in seasonality of air pollution in megacity Delhi, India. Environ Monit Assess184: 3199-3211

Harrison RM, Smith, DJT, and Luhana L (1996) Source Apportionment of Atmospheric Polycyclic Aromatic Hydrocarbons Collected from an Urban Location in Birmingham. UK. Environ Sci Technol, 30:825-832

Halsall CJ, Coleman PJ, Davis BJ, Burnett V, Waterhouse KS, Harding-Jones P Jones KD (1994) Polycyclic aromatic hydrocarbons in UK urban air. Environ Sci Techno 28: 2380-2386

Hazarika N, Jain VK, Srivastava A (2015) Source identification and metallic profiles of size-segregated particulate matters at various sites in Delhi. Environ Monit Assess, 187:602. DOI 10.1007/s10661-015-4809-7

Hazarika N, and Srivastava A (2016) Estimation of risk factor of elements and PAHs in size-differentiated particles in the National Capital Region of India. Air Quality, Atmosphere \& Health 1-14

Hegde P, Kawamura K (2017) Chemical Constituents of Carbonaceous and Nitrogen Aerosols over Thumba Region, Trivandrum, India. Arch Environ Contam Toxicol 73:456-473 DOI 10.1007/s00244-017-0426-5

Henry RC, Hidy GM (1979) Multivariate analysis of particulate sulfate and other air quality variables by principal components-I. Annual data from Los Angeles and New York. Atmos Environ $13: 1581$ - 1596

Ho KF, Lee SC, Chow JC, Watson JG (2003) Characterization of PM10 and PM2.5 source profiles for fugitive dust in Hong Kong. Atmos Environ 37(8):10231032

Ho KF, Ho SSH, Huang RJ, Liu SX, Cao JJ, Zhang T, Chuang HC, Chan CS, Hu D, Tian L, (2015) Characteristics of water-soluble organic nitrogen in fine particulate matter in the continental area of China. Atmospheric Environment. 106:252-261

Holzworth GC (1967) Mixing depths wind speed and air pollution potential for selected locations in the United States. J of Applied Meteorology 6:1039-1044

Page $19 / 29$ 
Hopke PK, (1991) Chapter 1 an Introduction to Receptor Modeling, (Ed.) Philip, K.H., Data Handling in Science and Technology, 1-10

Hsu A, Zomer A (2014) An Interactive Air-pollution Map. Available on. http://www. epi.yale.edu/the-metric/interactive-air-pollution-map (accessed 02.03.2016)

Izhar S, Goel A, Chakraborty A, Gupta T, (2016) Annual trends in occurrence of submicron particles in ambient air and health risk posed by particle bound metals, Chemosphere 146: 582-590

Jain S, Sharma SK, Vijyan N, Mandal TK (2020) Seasonal characteristics of aerosols $\left(\mathrm{PM}_{2.5}\right.$ and $\left.\mathrm{PM}_{10}\right)$ and their source apportionment using PMF: a four year study over Delhi, India. Environ Pollut 262:114337

Jain S, Sharma SK, Choudhary N, Masiwal R, Saxena M, Sharma A, Mandal TK, Gupta A, Gupta NC, Sharma C (2017) Chemical characteristics and source apportionment of $\mathrm{PM}_{2.5}$ using PCA/APCS, UNMIX and PMF at an urban site of Delhi, India. Environ Sci Pollut Res 24(17):14637-14656

Jaiprakash, Singhai, A., Habib, G, Raman RS, Gupta T, (2017) Chemical characterization of $\mathrm{PM}_{1.0}$ aerosol in Delhi and source apportionment using positive matrix factorization. Environ Sci Pollut Res 24: 445-462

Jaiprakash, Habib G, (2018) A technology-based mass emission factors of gases and aerosol precursor and spatial distribution of emissions from on-road transport sector in India. Atmos Environ. doi: 10.1016/j.atmosenv.2018.02.053

Jerrett M (2015) Atmospheric science: the death toll from air-pollution sources. Nature 525, 330-331

Jian ZY, Ho SSH, Xu J (2005) The chemical composition of inorganic and carbonaceous material in $\mathrm{PM}_{2.5}$ in Nanjing, China. Atmos Environ 39(20):3735-3749

Karar K, Gupta AK, Kumar A, Biswas AK (2006) Seasonal variations of PM10 and TSP in residential and industrial sites in an urban area of Kolkata, India. Environmental Monitoring and Assessment 118:369-381

Kaskaoutis DG (2014) Effects of crop residue burning on aerosol properties, plume characteristics, and long-range transport over northern India. J of Geophys Res 119: 5424-5444

Khan MF, Hirano K, Masunaga S, (2010) Quantifying the sources of hazardous elements of suspended particulate matter aerosol collected in Yokohama, Japan. Atmos Environ 44:2646-2657

Kavouras IG, Lawrence J, Koutrakis P, Stephanou EP, Oyola P (1999). Measurement of particulate aliphatic and polynuclear aromatic hydrocarbons in Santiago de Chile: source are conciliation and evaluation of sampling artifacts. Atmos Environ33:4977-4986

Kawamura K, Kobayashi M, Tsubonuma N, Mochida M, Watanabe T, and Lee M (2004) Organic and inorganic compositions of marine aerosols from East Asia: seasonal variations of water-soluble dicarboxylic acids, major ions, total carbon and nitrogen, and stable $\mathrm{C}$ and $20 \mathrm{~N}$ isotopic composition, in: Geochemical Investigations in Earth and Space Science: a Tribute to Isaac R. Kaplan, edited by: Hill RJ, Leventhal J, Aizenshtat Z, Baedecker MJ, Claypool G, Eganhouse R, Goldhaber M, and Peters K. The Geochemical Society Publication No. 9, 243-265

Khemani LT, Naik MS, Momin GA, Kumar R, Chatterjee RN, Singh G, Murty BVR (1985) Trace elements in the atmospheric aerosols at Delhi, North India, J Atmos Chem, 2:273-285

Khillare PS., Balachandran S, Meena BR (2004) Spatial and temporal variation of heavy metals in atmospheric aerosol of Delhi. Environmental Monitoring and Assessment, 90:1-21

Kondo Y, Miyazaki Y, Takegawa N,, Miyakawa T, Weber R.J, Jimenez JL, Zhang Q, and Worsnop DR (2007) Oxygenated and water-soluble organic aerosols in Tokyo. J Geophys Res, 112: D01203, doi:10.1029/2006JD007056

Kumar S, Aggarwal SG, Sarangi B, Malherbe J, Barre JPG, Berail S, Séby F, Donard OFX (2018) Understanding the Influence of Open-waste Burning on Urban Aerosols using Metal Tracers and Lead Isotopic Composition. Aerosol and Air Quality Research, 18, 2433-2446

Kumar S, Aggarwal SG, Gupta PK and Kawamura K (2015) Investigation of the tracers for plastic-enriched waste burning aerosols. Atmos Environ 108 49-58

Kumar S, Aggarwal SG, Malherbe J, Barre JPG, Berail S, Gupta PK and Donard OFX (2016) Tracing dust transport from Middle-East over Delhi in March 2012 using metal and lead isotope composition. Atmos Environ 132: 179-187

Laskin A, Smith JS, Laskin J (2009) Molecular characterization of nitrogen containing organic compounds in biomass burning aerosols using high resolution mass spectrometry. Environ Sci Technol, 43:3764-3771

Li J, Fang YT, Yoh M, Wang XM, Wu ZY, Kuang YW, Wen DZ (2012) Organic nitrogen deposition in precipitation in metropolitan Guangzhou city of southern China. Atmospheric Research, 113:57-67

Li J, Wang G, Aggarwal SG, Huang Y, Ren Y, Zhou B (2014) Comparison of abundances, compositions and sources of elements, inorganic ions and organic compounds in atmospheric aerosols from Xi'an and New Delhi, two megacities in China and India. Sci Total Environ 476:485-495 
Li, T.-C. et al. (2016) Inter-comparison of Seasonal Variation, Chemical Characteristics, and Source Identification of Atmospheric Fine Particles on Both Sides of the Taiwan Strait. Sci. Rep. 6, 22956; doi: 10.1038/srep22956

Mace KA, Kubilay N and Duce RA (2003) Organic nitrogen in rain and aerosol in the eastern Mediterranean atmosphere: An association with atmospheric dust. J Geophys Res 108:4320, doi: 10.1029/2002JD002997

Mandal P, Sarkar R, Mandal A, Saud T, (2014) Seasonal variation and sources of aerosol pollution in Delhi, India. Environ Chem Lett, 12 (4):529-534

Masih J, Singhvi R, Taneja A, Kumar K Masih H, (2012) Gaseous/particulate bound polycyclic aromatic hydrocarbons (PAHs), seasonal variation in north central part of rural India. Sustainable Cities and Society 3:30-36

Matawle JL, Pervez S, Dewangan S, Shrivastava A, Tiwari S, Pant P, Deb MK and Pervez Y (2015) Characterization of PM2.5 source profiles for traffic and dust sources in Raipur, India. Aerosol Air Qual Res, 15, 2537-2548

Mehra A, Farago ME, Banerjee DK (1998) Impact of fly ash from coal-fired power stations in Delhi, with particular reference to metal contamination. Environmental Monitoring and Assessment 50:15-35

Miyazaki Y, Aggarwal SG, Singh K, Gupta PK, Kawamura K (2009). Dicarboxylic acids and water-soluble organic carbon in aerosols in New Delhi, India in winter: Characteristics and formation processes, Journal of Geophysical Research: Atmospheres, 114, D19206

Mohan M, Bhati S, Sreenivas A, Marrapu P (2011) Performance Evaluation of AERMOD and ADMS-Urban for Total Suspended Particulate Matter Concentrations in Megacity Delhi. Aerosol and Air Quality Research 11: 883-894

MonkkonenP, UmaR,Srinivasan D, Koponen IK, Lehtinen KEJ, Hameri K, Suresh R, SharmaVP, Kulmala M(2004) Relationship and variations of aerosol number and $\mathrm{PM}_{10}$ mass concentrations in a highly polluted urban environment, New Delhi, India. Atmos Environ 38:425-433

Münevver N, Koçak M, (2018) Atmospheric water-soluble organic nitrogen (WSON) in the eastern Mediterranean: origin and ramifications regarding marine productivity. Atmos Chem Phys 18:3603-3618

Nagpure AS, Sharma K, Gurjar BR (2013) Traffic induced emission estimates and trends (2000-2005) in megacity Delhi. Urban Climate 4:61-73.

Nakamura T, Narita Y, Kanazawa K, Uematsu M (2020) Organic Nitrogen of Atmospheric Aerosols in the Coastal Area of Seto Inland Sea. Aerosol and Air Quality Research 20:1016-1025

Nehir M and Koçak M (2018) Atmospheric water-soluble organic nitrogen (WSON) in the eastern Mediterranean: origin and ramifications regarding marine productivity. Atmos Chem Phys 18:3603-3618

Ndiokwere CL (1984) A study of heavy-metal pollution from motor- vehicle emissions and its effect on roadside soil, vegetation and crops in Nigeria. Environmental Pollution Series B-Chemical and Physical, 7:35-42

Pacyna EG, Pacyna JM, Fudala J, Strzelecka-Jastrzab E, Hlawiczka S, Panasiuk D, Nitter S, Pregger T, Pfeiffer H, and Friedrich R (2007) Current and future emissions of selected heavy metals to the atmosphere from anthropogenic sources in Europe. Atmos Environ 41:8557-8566,

doi:10.1016/j.atmosenv.2007.07.040, 2007

Panther BC, Hooper MA, Tapper NJ, (1999) A comparison of air particulate matter and associated polycyclic aromatic hydrocarbons in some tropical and temperature urban environments. Atmos Environ, 33:4087-4099

Pandey PK, Patel KS, Lenicek J (1999) Polycyclic aromatic hydrocarbons: need for assessment of health risks in India. Study of an urban industrial location in India. Environ Monit Assess 59:287- 319

Pande JN, Bhatta N, Biswas D (2002). Outdoor air pollution and emergency room visits at a hospital in Delhi. Indian J Chest Dis Allied Sci. 44(1):13-19.

Pant P, Harrison RM, (2012) Critical review of receptor modelling for particulate matter: a case study of India. Atmos Environ 49:1-12

Pant P, Shi Z, Pope FD and Harrison RM (2017) Characterization of traffic-related particulate matter emissions in a road tunnel in Birmingham, UK: Trace metals and organic molecular markers. Aerosol Air Qual Res 17: 117-130

Panther BC, Hooper MA, Tapper NJ (1999) A comparison of air particulate matter and associated polycyclic aromatic hydrocarbons in some tropical and temperature urban environments. Atmos Environ 33:4087-4099

Park SS, Kim YJ, Kang CH (2002) Atmospheric polycyclic aromatic hydrocarbons in Seoul, Korea. Atmos Environ 36:2917-2924

Parrington JR (1983) The chemistry of background atmospheric particle collected at Mauna Loa Observatory. PhD Dissertation, Department of Chemistry, University of Maryland

Pathak AK, Yadav S, Kumar P, Kumar R (2013) Source apportionment and spatial-temporal variations in the metal content of surface dust collected from an industrial area adjoining Delhi, India. Sci Total Environ, 443:662-672

Page $21 / 29$ 
Patel A, Rastogi N, Gandhi U, Khatri N (2020) Oxidative potential of atmospheric $\mathrm{PM}_{10}$ at five different sites of Ahmedabad, a big city in Western India. Environ Poll, 268

Perrino C, Canepari S, Catrambone M, Torre SD, Rantica E, Sargolini, T, (2009) Influence of natural events on the concentration and composition of atmospheric particulate matter. Atmospheric Environment, 43:4766-4779

Perrino C, Tiwari S, Catrambone M, Torre SD, Rantica E, Canepari S (2011) Chemical characterization of atmospheric PM in Delhi, during different periods of the year including Diwali festival. Atmos Poll Res 2: 418-427

Pio CA, (2007) Climatology of aerosol composition (organic versus inorganic) at nonurban sites on a west-east transect across Europe J. Geophys. Res 112, D23S02, doi:10.1029/2006JD008038

Ram K, and Sarin MM (2010) Spatio-temporal variability in atmospheric abundances of EC, OC and WSOC over northern India. J. Aerosol Sci. 41(1):88-98

Ram K, Sarin MM (2011) Day-night Variability of EC, OC, WSOC and Inorganic Ions in Urban Environment of Indo-Gangetic Plain: Implications to Secondary Aerosol Formation. Atmos Environ 45:460-468

Ram K, Sarin MM, Tripathi SN (2012) Temporal Trends in Atmospheric PM2.5, PM10, Elemental Carbon, Organic Carbon, Water-Soluble Organic Carbon, and Optical Properties: Impact of Biomass Burning Emissions in The Indo Gangetic Plain. Environ Sci Technol 46:686-695

Larsen RK, Baker JE (2003) Source Apportionment of Polycyclic Aromatic Hydrocarbons in the Urban Atmosphere: A Comparison of Three Methods. Environ Sci Techno 37, 9:1873-1881

Rastogi N, Zhang X, Edgerton ES, Ingall E, Weber RJ (2011) Filterable water soluble organic nitrogen in fine particles over the south-eastern USA during summer. Atmos Environ 45:6040-6047

Rastogi N, Patel A, Singh A, Singh D (2015) Diurnal variability in secondary organic aerosol formation over the Indo-Gangetic Plain during winter using online measurement of water-soluble organic carbon. Aer Air Qual Res. DOI:10.4209/aaqr.2015.02.0097

Saarikoski S, Timonen H, Saarnio K, Aurela M, Järvi L, Keronen P, Kerminen V-M, and Hillamo R (2008) Sources of organic carbon in fine particulate matter in northern European urban air. Atmos Chem Phys 8:6281-6295

Salma I, Ocskay R, Raes N, and Maenhaut W, (2005) Fine Structure of Mass Size Distributions in an Urban Environment. Atmos Environ., 39:5363-5374

Sandradewi, J, Pre'vo^t, ASH, Weingartner E, Schmidhauser R, Gysel M, Baltensperger U, (2008) A study of wood burning and traffic aerosols in an Alpine valley using a multi-wavelength Aethalometer, Atmospheric Environment 42:101-112

Sarkar S, Khillare PS, Jyethi DS, Hasan A, Parween M (2010) Chemical speciation of respirable suspended particulate matter during a major firework festival in India. Journal of Hazardous Materials, 184, 321-330

Saud T, Gautam R, Mandal TK, Gadi R, Singh DP, Sharma SK, Dahiya M, Saxena M, (2012). Emission estimates of organic and elemental carbon from household biomass fuel used over the Indo-Gangetic Plain (IGP), India. Atmos Environ 61:212-220

Saxena M, Sharma A, Sena A, Saxena P, (2017) Saraswati, Mandal, T.K., Sharma, S.K., Sharma, C.: Water soluble inorganic species of PM10 and PM2.5 at an urban site of Delhi, India: Seasonal variability and sources. Atmos Res 184:12-125

Schauer JJ,. Fraser MP, Cass GR, and Simoneit BRT (2002) Source reconciliation of atmospheric gas-phase and particle-phase pollutants during a severe photochemical smog episode. Environ Sc. Technol 36:3806-3814, doi:10.1021/es011458j

Seinfeld JH and Pandis SN (1998) Atmospheric Chemistry and Physics from air pollution to climate change. New York. John Wiley and Sons

Seinfeld, J. H. and Pandis, S. N.: Atmospheric Chemistry and Physics: From Air Pollution to Climate Change, Second Edition, John Wiley and Sons, NY, USA, 2006

Shandilya K, Khare M, Gupta AB (2007) Suspended Particulate Matter Distribution in Rural-Industrial Satna and in Urban-Industrial South Delhi. Environ. Monit Assess, 128: 431-445

Sharma SK, Mandal TK, Saxena M, Sharma A, Gautam R (2014) Source apportionment of $\mathrm{PM}_{10}$ by using positive matrix factorization at an urban site of Delhi, India. Urban Clim 10:656-670

Sharma SK, Mandal TK, Jain S, Saraswati Sharma A, Saxena M, (2016) Source apportionment of PM 2.5 in Delhi, India using PMF model. Bull Environ Contam Toxicol 97(2):286-293

Sharma SK, Agarwal P, Mandal TK, Karapurkar SG, Shenoy DM, Peshin SK, Gupta A, Saxena M, Jain S, Sharma A, Saraswati (2017) Study on ambient air quality of megacity Delhi, India during odd-even strategy. MAPAN, 32(2):155-165 
Sharma SK, Mandal TK, Sharma A, Jain S (2018a) Carbonaceous Species of $\mathrm{PM}_{2.5}$ in Megacity Delhi, India during 2012-2016. Bull Environ. Contam Toxicol 100(5): 695-701

Sharma SK, Mandal TK, Sharma A, Jain S, (2018b) Seasonal and annual trends of carbonaceous species of PM 10 over megacity Delhi, India during 20102017. J. Atmos Chem 75(3):305-318

Sharma H, Jain VK, Khan ZH, (2007) Characterization and source identification of polycyclic aromatic hydrocarbons (PAHs) in the urban environment of Delhi. Chemosphere 66:302-310

Sharma H, Jain VK, Khan ZH (2007) Characterization and source identification of polycyclic aromatic hydrocarbons (PAHs) in the urban environment of Delhi. Chemosphere 66: 302-310

Singh RP, Kaskaoutis DG (2014) Crop residue burning: a threat to South Asian air quality. Trans Am Geophys Union 95:333-334

Smith DJT and Harrison RM (1996) Concentrations, trends and vehicle source profile of polycyclic aromatic hydrocarbons in the UK atmosphere. Atmos. Environ. 30: 2513-2525

Sharma SK, Sharma A, Saxena M, Choudhary N, Masiwal R, Mandal TK, Sharma C, (2016). Chemical characterization and source apportionment of aerosol at an urban area of Central Delhi. Atmos Pollu Res 7(1):110-121

Sharma SK, Choudhary N, Srivastava P, Naja M, Vijayan N, Kotnala G, Mandal TK (2020) Variation of carbonaceous species and trace elements in PM 10 at a mountain site in the central Himalayan region of India. Journal of Atmospheric Chemistry, 77 (3): 49-62

Shepherd, Philip, (1993) Polyvinyl Chi Municipal Solid Plastics in Combustion Impact Upon Di Emissions - A Synthesis of Views, Solid Waste Association of North America Silver Spring, Maryland, NREL/TP-430-5518 • UC Category: 249 • DE93010013, Prepared under Subcontract No. AS-2-12098-1, April 1993

Shivani, Gadi R, Sharma SK, Mandal TK, Kumar R, Sharma M, Kumar S, Kumar S (2018) Levels and sources of organic compounds in fine ambient aerosols over National Capital Region of India. Environ Sci Pollu Res 25:31071-31090

Shivani, Gadi R, Sharma SK, Mandal TK (2019) Seasonal variation, source apportionment and source attributed health risk of fine carbonaceous aerosol over National Capital Region, India. Chemosphere 237: 124500

Shen Z, Cao J, Arimoto R, Han,, Z, Zhang R, Han Y, Liu S, Okuda T, Nakao S, Tanaka S, (2009) lonic composition of tsp and PM 2.5 during dust storms and air pollution episodes at Xi'an, China. Atmos. Environ. 43: 2911-2918

Simoneit BR, Medeiros PM, Didyk BM (2005) Combustion products of plastics as indicators for refuse burning in the atmosphere. Environ Sci Technol 39(18): $6961-6970$

Song Y, Xie S, Zhang Y, Zeng L, Salmon LG, Zheng M (2006) Source apportionment of $\mathrm{PM}_{2.5}$ in Beijing using principal component analysis/absolute principal component scores and UNMIX. Sci. Total Environ 372(1):278-286

Spokes LJ, Yeatman SG, Cornell SE Jickells TD (2000) Nitrogen deposition to the eastern Atlantic Ocean: the importance of south-easterly flow. Tellus 52B:37-49

Shridhar V, Khillare PS, Agarwal T, Ray S (2010) Metallic species in ambient particulate matter at rural and urban location of Delhi. J. Hazard Mater 175:600607

Srivastava A, and Jain VK (2005) A study to characterize the influence of outdoor TSP and associated metals on the indoor environments in Delhi, J. Environ. Sci. Eng. 47: 222-231

Srivastava A and Jain VK (2007a) A study to characterize the suspended particulate matters in an indoor environment in Delhi, India, Build Environ. 42:20462052.

Srivastava A, and Jain VK, (2007b) Size distribution and source identification of total suspended particulate matter and associated heavy metals in the urban atmosphere of Delhi. Chemosphere, 68(3):579-589.

Srivastava A, and Jain VK (2007c) Seasonal trends in coarse and fine particle sources in Delhi by the chemical mass balance receptor model. Journal of Hazardous Materials, 144(1):283-291.

Srivastava A, and Jain VK (2008) Source apportionment of suspended particulate matters in a clean area of Delhi: A note. Transportation Research Part D: Transport and Environment, 13(1):59-63.

Srivastava A, Gupta S, and Jain VK (2009) Winter-time size distribution and source apportionment of total suspended particulate matter and associated metals in Delhi. Atmospheric Research, 92(1):88-99.

Stewart GJ, Nelson BS, Acton WJF, Vaughan AR, Farren NJ, Hopkins JR et al. (2020). Emissions of intermediate-volatility and semi-volatile organic compounds from domestic fuels used in Delhi, India. Atmos Chemis Phys Discussions, 1-45. 
Sun Y, Qi-xing Z, Jing A, Wei-tao L, Rui L, (2009) Chelator-enhanced phytoextraction of heavy metals from contaminated soil irrigated by industrial wastewater with the hyperaccumulator plant (Sedum alfredii Hance). Geoderma Vol. 150(1-2): 106-112.

Suneja J, Kotnala G, Kaur A, Mandal TK and Sharma SK (2020) Long-Term Measurements of SO2 Over Delhi, India, MAPAN-Journal of Metrology Society of India 35(1):125-133.

Tandon A, Yadav S, Attri AK (2008) City-wide sweeping a source for respirable particulate matter in the atmosphere. Atmospheric Environment 42:1064-1069.

Thurston GD and Spengler JD (1985). A Quantitative Assessment Of Source Contributions To Inhalable Particulate Matter Pollution In Metropolitan Boston, Atmos Environ, 1919-25.

Tian HZ, Wang Y, Xue ZG, Cheng K, Qu Y P, Chai FH, and Hao JM (2010). Trend and characteristics of atmospheric emissions of Hg, As, and Se from coal combustion in China, 1980- 2007, Atmos Chem Phys 10:11905-11919, doi:10.5194/acp10-11905-2010, 2010.

Tiwari S, Srivastava AK, Bisht DS, Bano T, Singh S, Behura S, Srivastava MK, Chate DM, Padmanabhamurty B(2009)Black carbon and chemical characteristics 62:193-209.1

Tobiszewski M, and Namieśnik J (2012) PAH diagnostic ratios for the identification of pollution emission sources. Environ Pollut 162:110-119.

Turpin B J, Huntzicker J J (1991) Secondary formation of organic aerosol in the Los Angeles basin: A descriptive analysis of organic and elemental carbon concentrations. Atmospheric Environment, 25 2:207-215.

Unceta N, Séby F, Malherbe J and Donard OFX (2010) Chromium speciation in solid matrices and regulation: A review. Anal Bioanal Chem, $397: 1097-1111$.

Venkataraman C, Lyons JM, and Friedlander SK (1994) Size Distributions of Polycyclic Aromatic Hydrocarbons and Elemental Carbon. 1. Sampling, Measurement Methods, and Source Characterization. Environ Sci Technol 28:555-562.

Venkataraman C, Habib G, Eiguren-Fernandez A, Miguel AH and Friedlander SK (2005) Residential biofuels in South Asia: Carbonaceous Aerosol Emissions and Climate Impacts. Science, 307:1454-1456, doi:10.1126/science.1104359.

Wang Z, Chen J, Yang P, Qiao X, Tian F (2007) Polycyclic aromatic hydrocarbons in Dalian soils: distribution and toxicity assessment. J of Environ Monit $9(2): 199-204$.

Watson JG, Turpin BJ, Chow JC (2001) The measurement process: Precision, accuracy, and validity. In: Cohen BS, McCammon CSJ (eds) Air Sampling Instruments for Evaluation of Atmospheric Contaminants, Ninth Edition, 9th edn. American Conference of Governmental Industrial Hygienists, Cincinnati, OH, pp 201-216.

Watson JG, Chow JC, Chen L-WA (2005) Summary of organic and elemental carbon/black carbon analysis methods and intercomparisons. AAQR 5:65-102.

Weber R J, Sullivan AP, Peltier RE, Russell A, Yan B, Zheng M, Gouw JD, Warneke C, Brock C, Holloway JS, Atlas EL and Edgerton E(2007) A study of secondary organic aerosol formation in the anthropogenic-influenced southeastern United States. J of Geophys Res, 112, D13302,

doi:10.1029/2007JD008408.

World Health Organization. (2000). WHO Regional Office for Europe, Copenhagen, Denmark, 2000. Chapter 5.9. Air Quality Guidelines, Second Edition.

Wu G, Ram K, Fu P, Wang W, Zhang Y, Liu X, Shatone EA, Pradhan BB, Man P, Arnico D, Panday K, Wan X, Bai Z, Kang S, Zhang Q, and Cong Z, (2019) WaterSoluble Brown Carbon in Atmospheric Aerosols from Godavari (Nepal), a Regional Representative of South Asia. Environ Sci Techno 53:3471-3479.

Xia L and Gao Y (2011) Characterization of trace elements in $\mathrm{PM}_{2.5}$ aerosols in the vicinity of highways in northeast New Jersey in the U.S. east coast, Atmos Poll Res 2,1:34-44.

Xavier Q, Alastuey A, Moreno N, Alvarez-Ayuso E, , García-Sa'nchez A, Cama J, Ayora C, Simo'n M (2006) Immobilization of heavy metals in polluted soils by the addition of zeolitic material synthesized from coal fly ash. Chemosphere 62:2,171-180

Yadav S, and Rajamani V (2006) Air quality and trace metal chemistry of different size fractions of aerosols in N-NW India-implications for source diversity. Atmos Environ 40: 698-712.

Yang RT, Herna'ndez-Maldonado AJ, Yang FH (2003) Desulfurization of Transportation Fuels with Zeolites Under Ambient Conditions. Science $301: 79-80$.

Yin J, Harrison RM, Chen Q, Rutter A, Schauer JJ (2010) Source apportionment of fine particles at urban background and rural sites in the UK atmosphere. Atmos. Environ. 44(6): 841-851.

Yu X, Yu Q, Zhu M, Tang M, Li S, Yang W, Wang X (2017) Water soluble organic nitrogen (WSON) in ambient fine particles over a megacity in South China: Spatiotemporal variations and source apportionment. J of Geophys Res: Atmospheres, 12213:045-13,060. https://doi.org/10.1002/2017JD027327

Yunker MB, Macdonald RW, Vingarzan R, Mitchell RH, Goyette D, Sylvestre S (2002) PAHs in the Fraser River basin. A critical appraisal of PAH ratios as indicators of PAH source and composition. Org Geochem 33(4):489-515.

Page $24 / 29$ 
Zhang Qi, Anastasio C, and Jimenez-Cruz M (2002) Water-soluble organic nitrogen in atmospheric fine particles (PM2.5) from northern California. J of Geophys Res 107, D11, 10.1029/2001jd000870.

Zhang Y, Cai J, Wang S, He K, Zheng M (2017) Review of receptor-based source apportionment research of fine particulate matter and its challenges in China. Sci Total Environ 586:917-929.

\section{Figures}
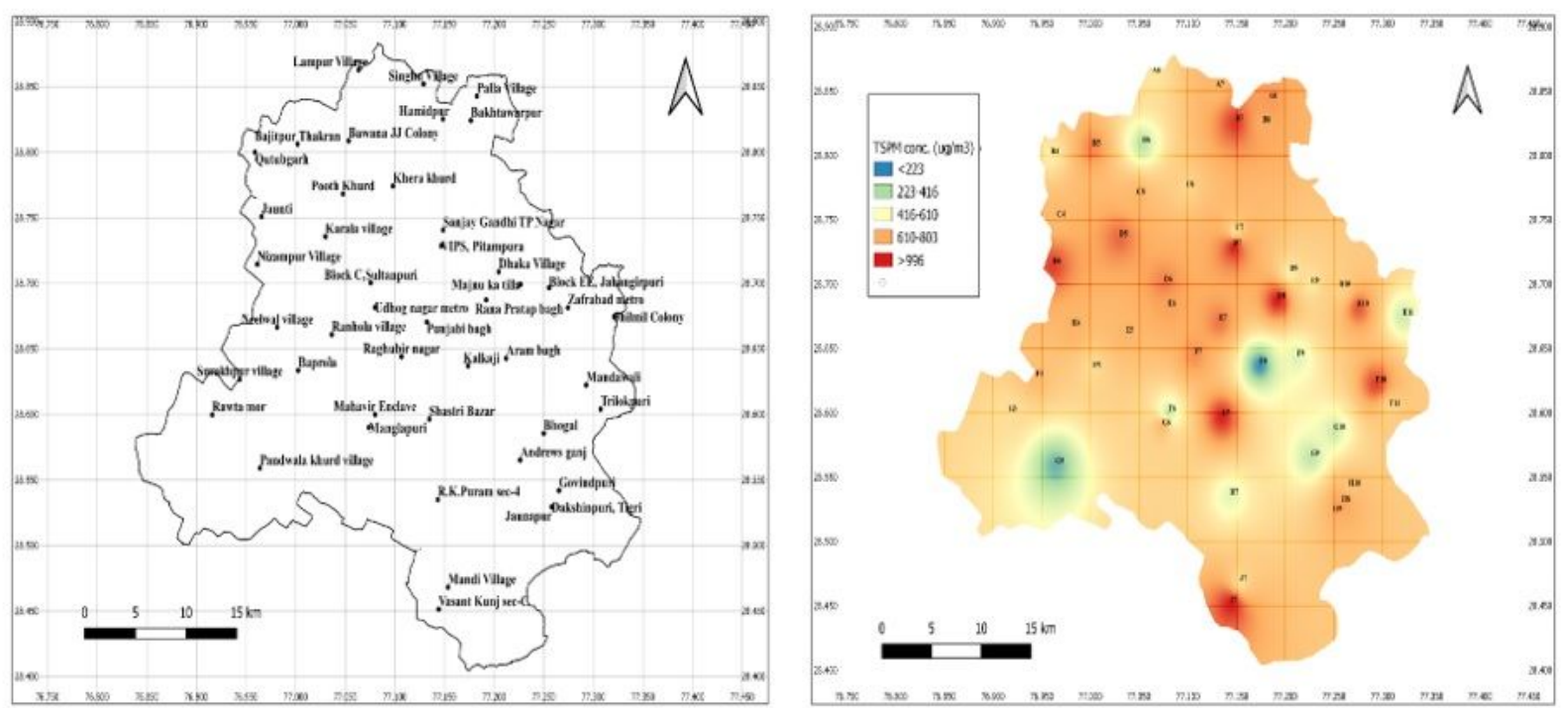

\section{Figure 1}

Delhi map showing a) grid wise location distribution b) TSP concentration spatially distributed at 47 grids of $5 \times 5 \mathrm{~km} 2$.

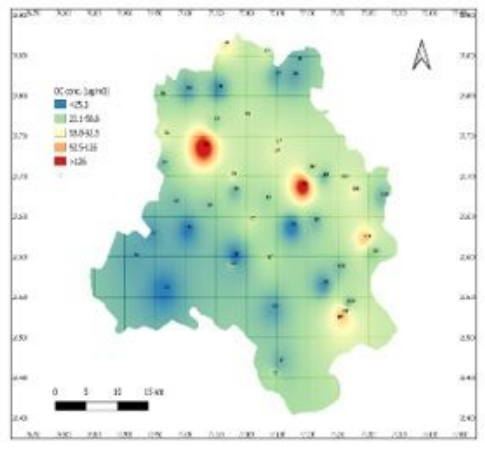

(a)

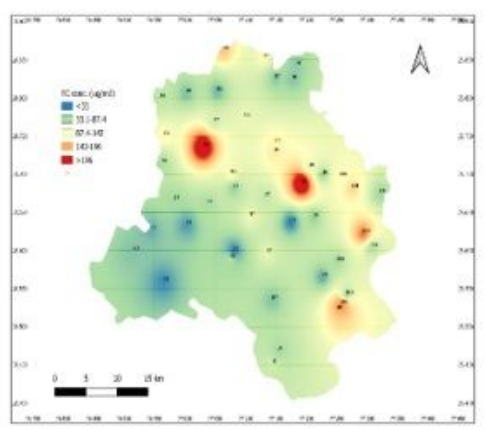

(c)

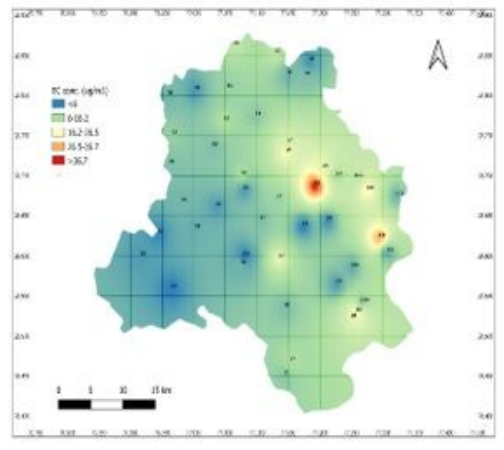

(b)

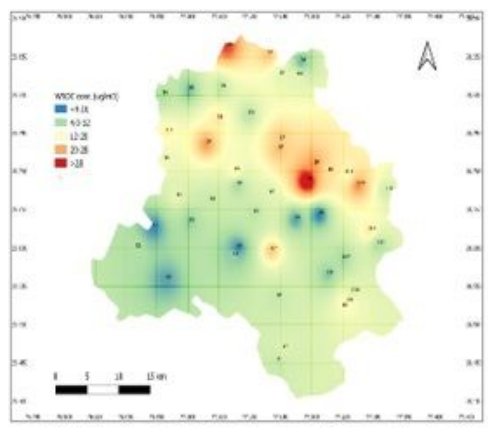

(d)

Figure 2

Spatial gridded distribution of a) Organic carbon b) Elemental carbon (c) Total Carbon (4) Water soluble organic carbon concentration in Delhi.. 


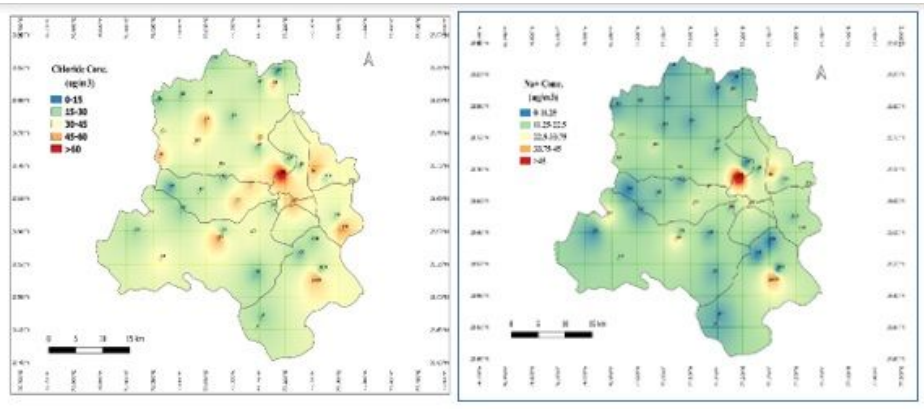

a) Chloride $\left(\mathrm{Cl}^{-}\right)$

b) Sodium $\left(\mathrm{Na}^{+}\right)$

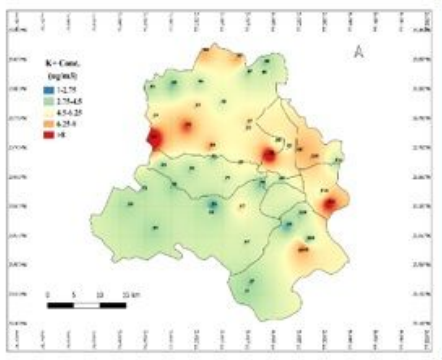

c) Potassium $\left(\mathbf{K}^{+}\right)$

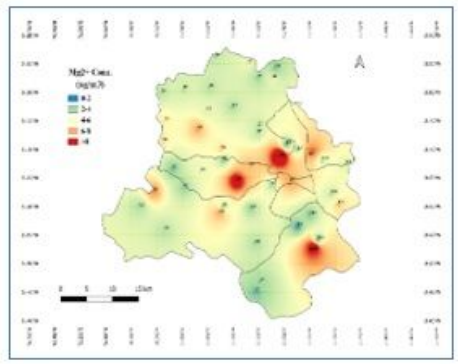

d) Magnesium $\left(\mathrm{Mg}^{+}\right)$

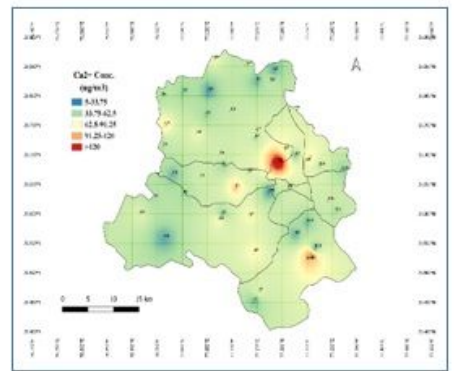

e) Calcium $\left(\mathrm{Ca}^{+}\right)$

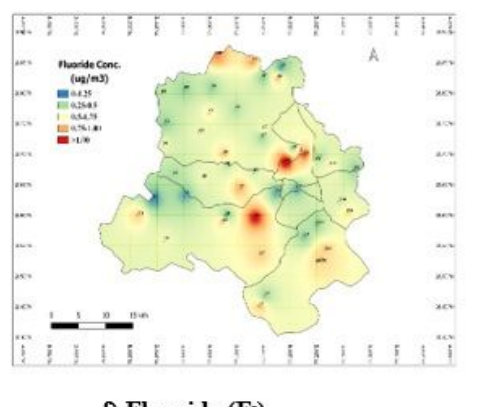

f) Fluoride $\left(\mathrm{F}^{-}\right)$

\section{Figure 3}

Gridded distribution of primary WSIS concentration in TSP: (a) Cl-, b) $\mathrm{Na}+, \mathrm{c}) \mathrm{K}+$, d) $\mathrm{Mg}+$, e) $\mathrm{Ca}+$ and f) F- 

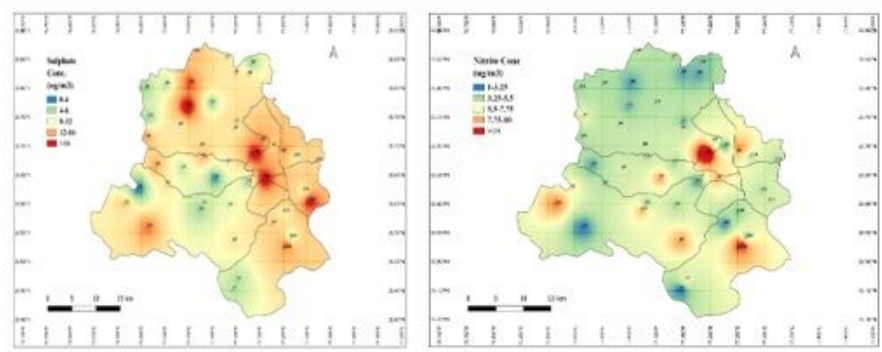

a) Sulphate $\left(\mathrm{SO}_{4}{ }^{2-}\right)$

b) Nitrite $\left(\mathrm{NO}_{2}^{-}\right)$

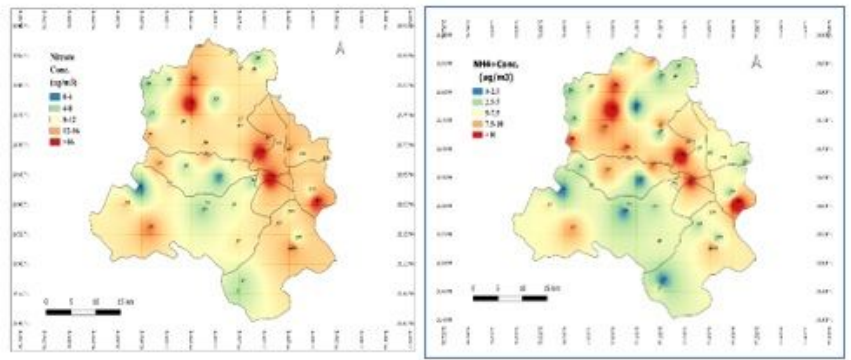

c) Nitrate $\left(\mathrm{NO}_{3}^{-}\right)$

d) Ammonium $\left(\mathrm{NH}_{4}^{+}\right)$

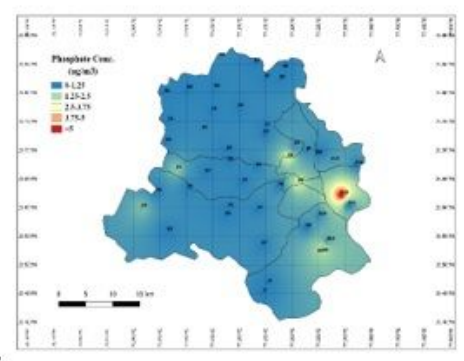

e) Phosphate $\left(\mathrm{PO}_{4}^{3-}\right)$

Figure 4

Gridded distribution of secondary WSIS concentration in TSP: (a) SO42-, b) NO2-, c) NO3-, d) NH4+ and e) PO43- 


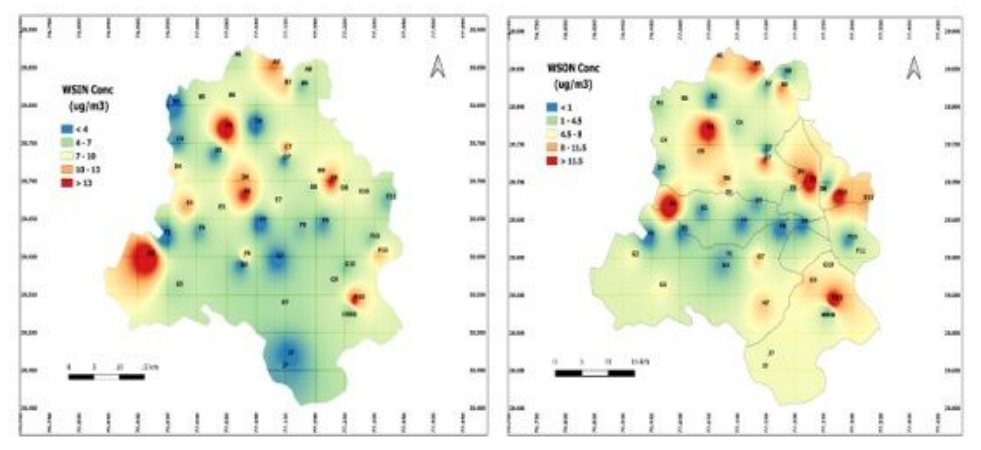

(a) water soluble inorganic nitrogen (WSIN) (b) water soluble organic nitrogen (WSON)

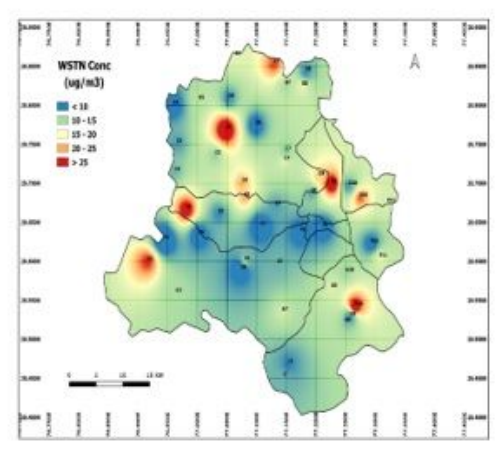

(c) water soluble total nitrogen (WSTN)

\section{Figure 5}

Spatial gridded distribution of a) water soluble inorganic nitrogen (WSIN), b) water soluble organic nitrogen (WSON) c) water soluble total nitrogen (WSTN) concentration in Delhi.

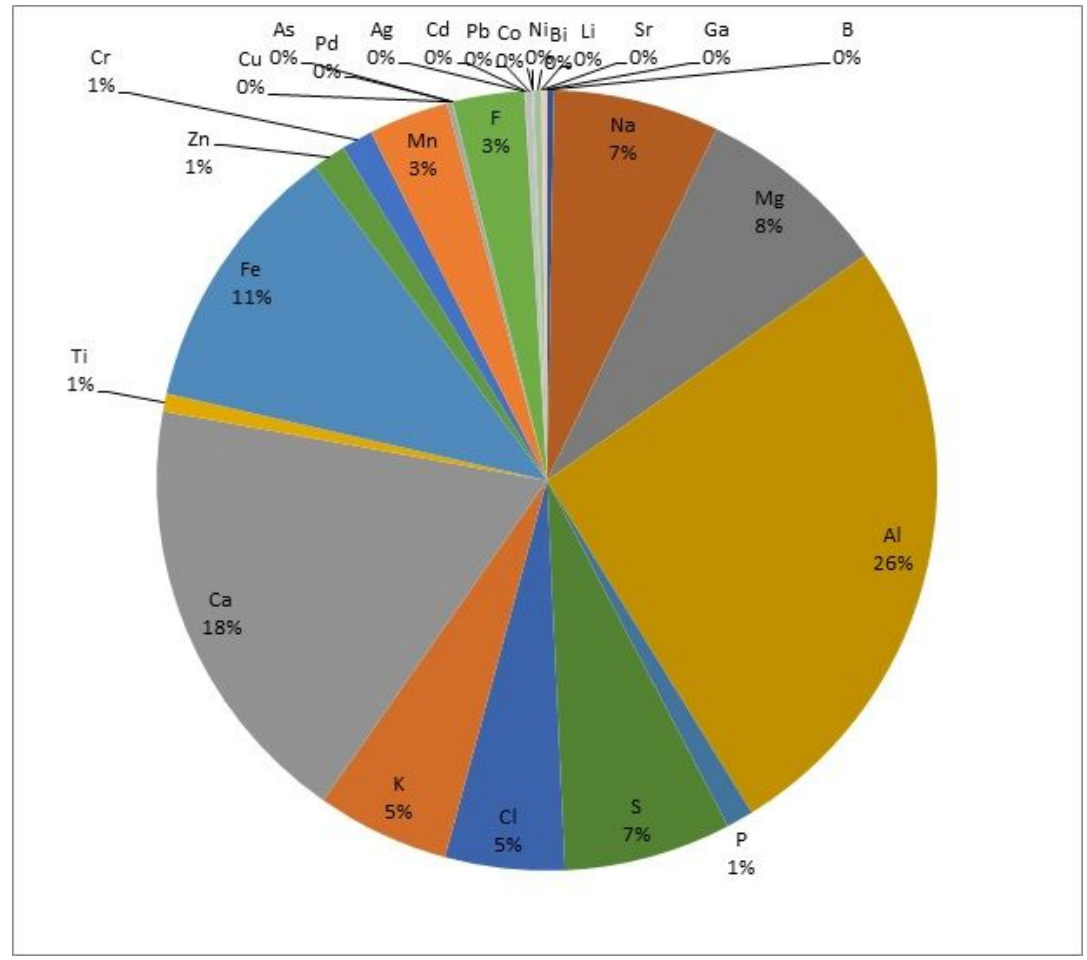

\section{Figure 6}

Percentage distribution of major and trace metals in Delhi 


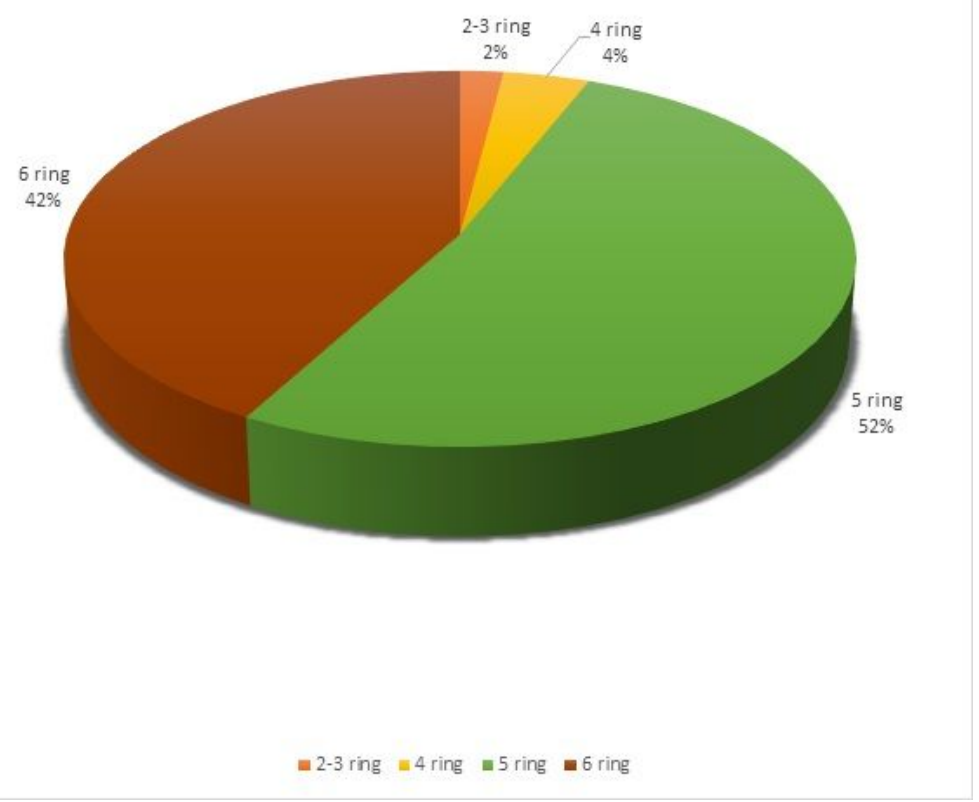

Figure 7

Percentage contribution of PAHs ring to the total PAHs concentration in ambient TSP.

\section{Supplementary Files}

This is a list of supplementary files associated with this preprint. Click to download.

- SupplementaryMSTSPDelhiR1.docx 